Yıldız, M. ve Aydoğmuş, M. (2021). Türkiye'de okuma güçlüğünü gidermeye odaklanan ilkokul düzeyindeki araştırmaların incelenmesi: 2000-2020 dönemi. Ana Dili Eğitimi Dergisi, 9(4), 1188-1225.

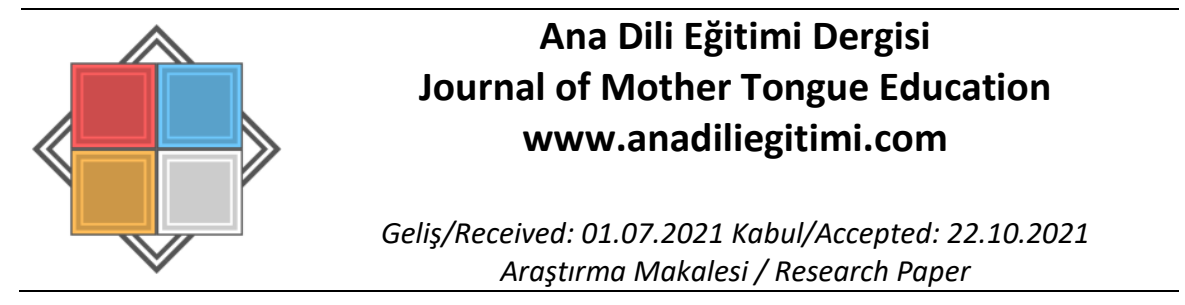

\title{
Türkiye'de Okuma Güçlüğünü Gidermeye Odaklanan İlkokul Düzeyindeki Araştırmaların İncelenmesi: 2000-2020 Dönemi
}

\author{
Mustafa YILDIZ* \\ Mücahit AYDOĞMUŞ**
}

\begin{abstract}
Öz
Bu araştırmanın amacı 2000-2020 yılları arasında Türkiye'de ilkokul düzeyindeki öğrencilerin okuma güçlüğünü gidermeye dönük bilimsel çalışmaları bütüncül bir bakış açısıyla değerlendirmektir. Araştırmada sistematik derleme yöntemi esas alınmıştır. Alanyazın taraması sonucunda birtakım dâhil etme ve dışarıda bırakma kriterlerine göre belirlenen 58 çalışma; çalışmaların genel özellikleri, katılımcıların özellikleri ve müdahale uygulamalarının özellikleri boyutlarıyla incelenmiştir. Verilerin analizinde betimsel analiz ve tümevarımsal içerik analizi yöntemleri kullanılmıştır. Araştırma sonuçları, okuma güçlüğü çalışmalarının en çok 4. sınıf öğrencileriyle gerçekleştirildiğini ve bu çalışmaların genellikle nitel araştırmalar olduğunu göstermektedir. Çalışmalarda uygulanan müdahale programlarının genel olarak araştırmacılar tarafından katılımcıların özellikleri dikkate alınarak hazırlanan etkinliklerden oluştuğu, okuma güçlüğünü gidermede akıcı okuma stratejilerinin kullanıldığı ve müdahalelerin başarılı olduğu görülmektedir. Türkiye'de okuma güçlüklerini gidermeye dönük çalışmalarda teknoloji kullanımının yaygınlaşmasına, daha sistematik müdahale programlarına ve belirli standartlara sahip veri toplama araçlarına ihtiyaç olduğu anlaşılmaktadır.
\end{abstract}

Anahtar Kelimeler: Okuma güçlüğü, akıcı okuma, sistematik derleme, zayıf okuyucular, öğrenme güçlüğü

\section{Examination of Primary School-Level Research Focusing on Overcoming Reading Disability in Turkey: 2000-2020 Period}

\begin{abstract}
This research aims to evaluate the studies involving the intervention practices toward reading disabilities of primary school students in Turkey between 2000-2020. The study is based on a systematic review. As a result of the literature review, 58 studies were determined according to some inclusion and exclusion criteria and examined with the dimensions of general features, the characteristics of the participants, and intervention practices' features. Descriptive and inductive content analysis methods were used for analyzing the data. Research results showed that studies of overcoming reading disability carried out substantially with 4th-grade students and generally utilized qualitative research methods. The intervention programs generally consisted of activities prepared by the researchers considering the characteristics of the participants, fluent reading strategies were used to overcome the reading difficulties, and the interventions were successful. It is understood that there is a need for widespread use of technology, more systematic intervention programs and data collection tools with certain standards in studies aimed at eliminating reading difficulties in Turkey.

Keywords: Reading disability, fluent reading, systematic review, poor readers, learning disability
\end{abstract}

\footnotetext{
* Prof. Dr., Gazi Üniversitesi, Gazi Eğitim Fakültesi, Temel Eğitim Bölümü, Ankara, mustafa@gazi.edu.tr, ORCID: orcid.org/0000-0003-3885-5322

** Arş. Gör., Ondokuz Mayıs Üniversitesi, Eğitim Fakültesi, Temel Eğitim Bölümü, Samsun,

mucahit.aydogmus@omu.edu.tr, ORCID: orcid.org/0000-0002-1418-1100
} 


\section{Giriş}

Okuma, bireylerin akademik ve sosyal yaşamları için önemli bir beceridir. Çünkü okumanın, hayatın diğer alanlarıyla ilişkili olan birçok becerinin gelişmesinde ve bireyin toplumsal ilişkilerini düzenleyebilmesinde temel teşkil ettiği söylenebilir. Buradan hareketle okumanın hayatın her alanında kullanılan bir yaşam becerisi olduğu ifade edilebilir (Akyol ve Çoban Sural, 2021). Okuma bireyin ilkokulda kazanması, devam eden eğitim öğretim süreçlerinde ise geliştirmesi gereken bir beceridir. Çünkü okumada yetkinlik, öğrenme süreçlerindeki akademik başarıya zemin oluşturmaktadır (Akyol, Yıldırım, Ateş, Çetinkaya ve Rasinski, 2014). Her ne kadar bireylerin tamamından iyi birer okuryazar olmaları beklense de bazı öğrenciler; görme, işitme, seslendirme, sıralama, sınıflandırma, ilişkilendirme, eşleştirme, analiz, sentez ve değerlendirme gibi zihinsel işlemlerin birlikte işe koşulduğu okuma süreçlerinde başarılı olamamaktadırlar (Coltheart, 2005; Tracey ve Morrow, 2006). Öğrencilerin beklenen okuma performansına sahip olmamalarında görme ve işitme kusurları (Akyol, Temur ve Erol, 2019), takvim yaşı, cinsiyet, beyin başatlığı, genel zekâ, zihinsel düşünme, özel bilişsel problemler, dikkat, sözel dil gelişimi, aile (Akyol, 2018) gibi okumaya hazır oluşla ilgili faktörler ve okul öncesi eğitim, okuma motivasyonu, okuma tutumu (Bıyık ve Erdoğan, 2017) gibi faktörler etkili olmaktadır. Ancak bazı öğrenciler bu etmenler bakımından akranlarıyla benzer özelliklere sahip olduğu halde akranlarına göre daha zayıf performans göstermektedirler (Akyol ve Çoban Sural, 2021; Deniz, Yorgancı ve Özyeşil, 2009). Bir başka ifadeyle; çeşitli okuma problemleri olan bu öğrenciler okuma güçlüğü yaşamaktadırlar.

Okuma güçlüğünün alanyazında okuma bozukluğu, okuma problemi, disleksi ve okuma zorluğu gibi farklı kavramlarla ifade edildiği görülmektedir. Kavramsal bütünlüğün sağlanması adına bu araştırmada okuma güçlüğü kavramının kullanılması uygun görülmüştür. Disleksi olarak da adlandırılan okuma güçlüğü, yazma güçlüğü (disgrafi) ve matematik öğrenme güçlüğü (diskalkuli) ile birlikte nörogelişimsel bir bozukluk olarak tanımlanan özel öğrenme güçlüğünün alt gruplarından biridir (American Psychiatric Association, 2013). Özel öğrenme güçlüğü yaşayan öğrenciler okuma, anlama, dil kullanımı, yazılı ifade, dinleme, düşünme veya matematiksel süreçlerde düşük başarı gösterirler (Bender, 2012; Santrock, 2018). Okuma güçlüğü; yaş seviyesine göre normal zekâ düzeyi ve eğitim imkânlarına sahip olunmasına rağmen kelime okuma doğruluğu, okuma hızı, akıcı okuma ve okuduğunu anlamada problemler yaşamayı (American Psychiatric Association, 2013; Morrison, 2016) ve ses bilgisel farkındalık, kelime hazinesi ve hecelemede görülen sınırlııkları (Armbruster, 2010) ifade etmektedir. Bu öğrencilerin okuma güçlüğü yaşamalarında; motivasyon ve ilgi eksikliği, aile ve çevreden kaynaklanan problemler, entelektüel becerilerin zayıflığı ve okul öncesi eğitim almama gibi faktörler etkili olabilmektedir (Snow, Burns ve Griffin, 1998). Ayrıca okuma güçlüğü; motor becerilerdeki problemler, işitsel problemler ve görsel problemler olmak üzere üç türde değerlendirilmekte ve öğrenci bu problemlerin birden çoğuna aynı anda sahip olabilmektedir (Ward, 2001). Dolayısıyla okuma güçlüğünün; beynin grafiksel sembol işleme aktivitelerinde ortaya çıkan ve bireyin okuma ve yazma becerilerini etkileyen (Rello ve Baeza Yates, 2013) bir problem olduğu söylenebilir. Okuma güçlüğü; okuma ve yazma problemlerinin bir sebebi olmasının yanı sıra Narimani ve Aghajani'ye (2004) göre ilkokul öğrencilerinin akademik başarısızlıklarının temel problemi olarak görülmektedir ve akademik problemlerin \%25'inin okuma güçlüğünden kaynaklandığı ortaya koyulmaktadır. Bireylerin akademik başarılarında bu denli etkili olan okuma güçlüğünün ender görülen bir problem olduğunu söylemek de zordur. Nitekim araştırmalar (Pennington, 2002; Rello ve Baeza Yates, 2013; Siegel, 2006) okuma güçlüğünün insanların \%5 ile \%20'sinde görüldüğünü, bu oranın okul çağı çocuklarında \%3 ile \%20 arasında olduğunu göstermektedir (Lyon, Fletcher ve Barnes, 2003; Saviour vd., 2008; Shaywitz vd., 2002; Snowling, Hulme ve Nation, 2020). Ayrıca özel eğitime gereksinim duyan öğrencilerin \%25'inin okuma güçlüğü yaşadığı (Yurdakal, 2017) belirtilmektedir. Bu sonuçlar; okuma güçlüğü yaşayan öğrencilerin hangi özelliklere sahip olduğu, okuma güçlüğünün belirtileri, tanılama süreci ve okuma güçlügünün giderilmesinde kullanılan yöntem ve tekniklere odaklanılması gerektiğini göstermektedir.

Okuma güçlüğünün, organik (beyin gelişme süreci), genetik, çevresel ve biyokimyasal (zihinsel faaliyetler) süreçlerden etkilendiği (Mastropieri ve Scruggs, 1997) ve birtakım belirtilerinin olduğu söylenebilir. Bu belirtiler çok küçük yaşlarda ortaya çıkmakla birlikte çoğunlukla okul çağına kadar anlaşılamamaktadır (Akın, 2020). Okuma güçlüğü, okuma ve yazma becerilerinin kullanılmaya 
Türkiye'de Okuma Güçlüğünü Gidermeye Odaklanan İlkokul Düzeyindeki Araştırmaların İncelenmesi: 20002020 Dönemi

başlanmasından sonra gözlemlenebildiği için genellikle ilkokulda fark edilebilmektedir (Hultquist, 2006). Kelime tanımada ve akıcı okumada problem yaşamanın, okuma güçlüğünün en temel belirtileri olduğu söylenebilir (Herrmann, Matyas ve Pratt, 2006). Ayrıca ses farkındalığının zayıflığı, ses ve harfi eşleştirmede güçlük, kelimeleri seslerine ayıramama, kelime hataları yapma, akranlarından daha yavaş okuma gibi faktörler de okuma güçlüğü belirtilerindendir (Rayner vd., 2001; Vellutino vd., 2004; Walker ve Rastatter, 2003; Ziegler vd., 2003). Yurdakal'a (2017) göre ise okuma güçlüğü belirtilerinden bazıları; bozuk ve anlamsız okuma, akranlarından daha düşük okuma performansı gösterme, dikkat eksikliği, odaklanma problemi, çabuk sıkılma, vurgu ve tonlama hataları yapma, akıcı okuyamama, bazı harf ve rakamları ters yazma, hiperaktivite, dağınıklık, yavaş okuma, atlayarak okuma, kelime tekrarı ve yanlış okumadır. Bu belirtilerin fark edilmesinde şüphesiz öğretmenlerin rolü çok önemlidir çünkü öğretmenler öğrencilerinin okuma becerilerini ve kişilik özelliklerini gözlemleme imkânına sahiptir. Öğrencilerin okuma güçlüğü belirtilerinin fark edilmesiyle birlikte tanılama sürecinin ilk adımının atıldığını söylemek mümkündür. Okuma güçlüğü ile ilgili problemlerin belirlenmesi, bu problemlerin giderilmesine yönelik uygulamaların ortaya koyulması için bir ön gereklilik olarak görülmektedir (Baydık, Ergül ve Bahap Kudret, 2012). Türkiye'de, özelde okuma güçlüğü genelde ise özel öğrenme güçlüğü; tıbbi tanılama ve eğitsel değerlendirme olmak üzere iki aşamada belirlenmektedir (Akın, 2020). Sağlık kurumlarında yapılan tıbbi tanılamada algı ve zekâ testleriyle psikolojik süreç değerlendirmesi, Rehberlik Araştırma Merkezlerinde de eğitsel değerlendirme yapılmakta ve öğrencinin ihtiyacı olan alanlara yönelik rapor hazırlanmaktadır (Özmen, 2017). Okuma güçlüğünün belirlenmesinde tıbbi tanılama ve eğitsel değerlendirme süreçlerinin yanı sıra, okuma becerileriyle ilgili standartlaştırılmamış ölçme ve değerlendirme araçları da kullanılabilmektedir. Örneğin; Ekwall ve Shanker (1988) tarafından geliştirilen ve Akyol (2005) tarafından Türkçeye uyarlanan 'Yanlış Analizi Envanteri' öğrencilerin kelime tanıma, okuma hızı ve okuduğunu anlama gibi okuma becerilerinin değerlendirilmesinde öğretmenlere kolaylık sağlayabilmektedir. Okuma güçlüğü belirlendikten sonraki aşamada ise planlama, müdahale programları hazırlama ve bunları etkili bir şekilde uygulama gelmektedir. Çünkü okuma güçlüğü yaşayan öğrenciler, intiyaç duydukları öğretim hizmetlerini alamadıklarında, devam eden yıllarda okuma becerileri çok az gelişmekte, sınıf düzeyinin altında okuma performansı göstermekte ve zayıf okuyucular olarak kalmaktadırlar (Bursuck ve Blanks, 2010; National Reading Panel, 2000; Stanovich, 2000). Dolayısıyla okuma güçlüğü yaşayan öğrencilerin ilgi ve ihtiyaçlarına yönelik programların geliştirilmesi ve uygulanmasının, okuma güçlüğünün giderilmesinde kritik rol oynadığı söylenebilir.

Okuma güçlüğünün giderilmesinde farklı uygulamalardan (strateji, yöntem, model ve teknik vb.) yararlanıldığı görülmektedir. Bunlardan en çok; rehberli okuma (Yurdakal, 2017), tekrarlı okuma (Armbruster, Lehr ve Osborn, 2010; Bender ve Larkin, 2003), eşli okuma (Rasinski, Padak, Linek ve Sturtevant, 1994; Stahl ve Heubach, 2005), koro okuma (Paige, 2011), eko okuma (Hudson, Lane ve Pullen, 2005; Kato, 2012), paylaşımlı okuma (Sugara, 2012) ve okuyucu tiyatroları (Reutzel ve Cooter, 2012) gibi akıcı okuma stratejilerinin kullanıldığı söylenebilir. Ayrıca; okuma öncesi, sırası ve sonrası okuma stratejileri, Fernald Tekniği (Polloway vd., 2013), Okuma Yetkinliği Programı (Engelmann vd., 1999), Rewards Okuma Programı (Vachon, Gleason ve Archer, 2000), Doğal Okuma Programı (Inhot, Matsoff, Gavin ve Hendrickson, 2001), Günlük Kitap Okuma Programı (Spandel, Nathan ve Robb, 2001), Çok Duyulu Okuma Metodları (Mercer, 1997), Nörolojik Etki Yöntemi (Heckelman, 1969), Pratik Stratejilerle Erken Okuryazarlığa Yardım Programı (Begeny, 2009), Bireyselleştirilmiş Okuma Programı (Akyol ve Çoban Sural, 2021; Akyol ve Ketenoğlu Kayabaşı, 2018; Çayır ve Balcı, 2017), 3P Metodu (Burns, 2006; Dağ, 2010), boşluk tamamlama tekniği (Dağ, 2010; James, 2004), Bir Öğretmen Bir Yardımcı Modeli (Dağlı Gökbulut, Akçamete ve Güneyli, 2020), Paragrafın Önceden Dinlenmesi Stratejisi (Doğuyurt ve Doğuyurt, 2016), Altı Dakika Yöntemi (Adams ve Brown, 2009), Yapılandırılmış Akıcı Okuma Yöntemi (Keskin, 2012), PQRS Stratejisi (Westwood, 2001), Sesbilgisel Farkındalık Eğitimi (Yücel, 2009) ve Kelime Kutusu Stratejisi (Joseph, 2002) gibi uygulamalar da okuma güçlüğünün giderilmesinde kullanılabilmektedir. Alanyazında bireylerin okuma güçlüğünü gidermeye yönelik müdahale uygulamalarını (Ege, 2019; Gül, 2019; Peksoy, 2018; Sirem, 2020), okuma güçlüğü yaşayan çocukların becerilerini (Küçükcaymaz, 2011; Seyis, 2021; Şen, 2016), okuma güçlüğü olan öğrencilerle ilgili öğretmenlerin, öğrencilerin ve ebeveynlerin görüşlerini (Yurdakal, 2014), öğretmenlerin bilgi, 
farkındalık ve tutumlarını (Akçay, 2014; Şahin, 2019) okuma güçlüğü olan ve normal öğrencilerin becerilerini (Alatlı, 2020; Ekşi Sınır, 2020; Karcıoğlu, 2020; Seçkin, 2012) ve okuma güçlüğü olan öğrencilerle çalışan öğretmenlerin yeterliklerini (Kızılkaya, 2021) inceleyen araştırmaların ve ölçek geliştirme çalışmalarının (Topal, 2019; Tosun, 2019) yer aldığı görülmektedir. Derleme çalışmaları açısından incelendiğinde ise alanyazında; öğrenme güçlüğü konusunda yayınlanan çalışmaların incelendiği (Deveci ve Koç, 2020; Görgün ve Melekoğlu, 2019), özel öğrenme güçlüğü olan öğrencilerin okuduğunu anlama becerilerine ilişkin yapılan çalışmaların incelendiği (Pürsün ve Sarı, 2020; Yıldız ve Melekoğlu, 2020), öğrenme güçlüğünde teknoloji kullanımı ile ilgili çalışmaların incelendiği (Doğan ve Delialioğlu, 2020) ve özel öğrenme güçlüğü olan öğrencilerin yazma becerilerine ilişkin yapılan çalışmaların incelendiği (illker ve Melekoğlu, 2017) görülmektedir. Ancak öğrenme güçlüğünün giderilmesine dönük müdahale uygulamalarını içeren çalışmaların incelendiği bir derleme çalışmasına rastlanılmamıştır. Dolayısıyla bu araştırma Türkiye'de ilkokul düzeyinde okuma güçlüğünün giderilmesinde kullanılan müdahale uygulamalarına odaklanması bakımından alanyazındaki diğer derleme çalışmalarından farklılaşmaktadır. Öğrenme güçlüğü tanısı olan öğrencilerin yaklaşık \%80'inin okuma güçlüğü yaşadığı (Fielding Barnsley, 2000) dikkate alındığında; alanda özellikle okuma güçlüğünün giderilmesine yönelik derleme çalışmalarına ihtiyaç olduğu söylenebilir. Buradan hareketle okuma güçlügünü gidermeye dönük müdahale uygulamalarını içeren araştırmaları bütüncül bir bakış açısıyla değerlendirmek bu araştırmanın temel amacını oluşturmaktadır. İlkokul öğrencilerinin okuma güçlüğünün giderilmesinde uygulanan müdahalelerin derlenerek, kapsamlı bir şekilde ortaya koyulmasının alana katkı sağlayacağı düşünülmektedir. Ayrıca bu araştırmanın sonuçlarının okuma güçlüğü yaşayan öğrencilerin öğretmenlerine ve ailelerine önemli dönütler sağlayacağı düşünülmektedir. Çünkü derleme çalışmalarının kapsamlı kanıtlar oluşturmada güçlü bir yöntem olduğu söylenebilir (Gough, Thomas ve Oliver, 2012). Türkiye'de 2000-2020 yılları arasında yapılan çalışmalar çerçevesinde; ilkokul düzeyinde okuma güçlüğü yaşayan bireylerin özellikleri, okuma güçlüğünün belirlenme süreçleri, sınıf düzeylerine göre akıcı okuma becerileri, okuma güçlüğünün giderilmesinde kullanılan yöntemler ve uygulama süreleri ile ilgili bulguları sistematik bir yaklaşımla ortaya koymayı amaçlayan bu araştırmada aşağıdaki sorulara cevap aranmaktadır:

1. Türkiye' de okuma güçlüğünü gidermeye odaklanan ilkokul düzeyindeki araştırmaların genel özellikleri (yayın yılı, yayın türü, yöntemi, deseni, veri toplama araçları) nelerdir?

2. Türkiye'de okuma güçlügünü gidermeye odaklanan ilkokul düzeyindeki araştırmalarda yer alan katılımcıların özellikleri (sınıf düzeyi, cinsiyet, katılımcı sayısı, okuma problemleri, okuma problemlerinin belirlenmesi, bilişsel-sosyal-duygusal özellikleri) nelerdir?

3. Türkiye'de okuma güçlügünü gidermeye odaklanan ilkokul düzeyindeki araştırmaların müdahale programlarının özellikleri (kapsamı ve içeriği, süresi, etkileri ve sonuçları) nelerdir?

\section{Araştırmanın Modeli}

\section{Yöntem}

Bu araştırmada sistematik derleme yöntemi kullanılmıştır. Sistematik derleme bir probleme cevap bulmak için o alanda yayınlanan tüm çalışmaların kapsamlı bir biçimde taranmasıyla birtakım dâhil etme ve dışarıda bırakma kriterleri kullanılarak belirlenen çalışmaların sentezlenmesi olarak tanımlanabilir (Burns ve Grove, 2018; Higgins vd, 2019). Sistematik derleme çalışmaları bilimsel bilgileri içerdiğinden incelenen problemle ilgili güçlü yanıtlar üretmeleri bakımından önemlidirler (Karaçam, 2013). Sistematik derleme çalışmaları; objektif olması, alanyazın taramasının bir yöntem dâhilinde yapılması, kapsamlı ve tekrar edilebilir olması, çalışmaların belirlenmesinde kullanılan kriterlerin açıkça belirtilmesi, sentezleme sürecinde en küçük bulguların bile derlemeye dâhil edilmesi bakımından kabul görmektedir (Hemingway ve Brereton, 2009; Moule, Aveyard ve Goodman, 2016). Bu araştırma da Türkiye'de 2000-2020 yılları arasında yayınlanan okuma güçlüğü çalışmalarını derlemeyi amaçladığından sistematik derleme yöntemi esas alınmıştır. 
Türkiye'de Okuma Güçlüğünü Gidermeye Odaklanan Iilkokul Düzeyindeki Araştırmaların İncelenmesi: 20002020 Dönemi

\section{Verilerin Toplanması ve Veri Analizi}

Sistematik derleme süreci; Moher vd. (2009) tarafından önerilen aşamalar çerçevesinde gerçekleştirilmiştir. Bu aşamalar: 1- ilgili çalışmaları tanımlama ve dâhil etme/ dışarıda bırakma kriterlerini belirleme, 2- Alanyazın tarama stratejisi geliştirme, 3- Alanyazın taraması ile dâhil edilebilecek potansiyel çalışmaları belirleme, 4- Dâhil edilen çalışmaları tanımlama ve değerlendirme, 5- Araştırma bulgularını analiz etme ve sentezlemedir.

\section{Dâhil Etme ve Dışarıda Bırakma Kriterlerinin Belirlenmesi}

Veri toplama sürecinde öncelikle incelenecek çalışmalar için birtakım uygunluk kriterleri belirlenmiştir ve yalnızca bu kriterlerin tamamını sağlayan araştırmalar bu çalışmaya dâhil edilmiştir. Bu kriterler şunlardır:

- $\quad$ ilkokul öğrencileri ile yürütülmüş olma (Çalışmanın yayınlandığı yıl ilkokul düzeyinde olan 5. sınıf öğrencileri ile yürütülen çalışmalar da kapsama dâhil edilmiştir).

- Okuma problemi olan ancak herhangi bir zihinsel veya bedensel yetersizliği olmayan öğrencilerle yürütülmüş olma.

- Okuma problemleri test ya da raporlarla belirlenmiş öğrencilerle yürütülmüş olma.

- Okuma problemlerini gidermeye yönelik müdahale uygulamalarını içerme.

- 2000-2020 yılları arasında yayınlanmış olma.

- Türk öğrencilerle gerçekleştirilmiş olma.

- Türkçe ya da İngilizce dillerinde yayınlanmış olma.

- Erişime açık olma.

- Hakemli dergide yayınlanmış olma (makaleler için).

- Tezden üretilmemiş olma (makaleler için) (Tezlerin erişime açık olmaması durumunda tezden üretilen makaleler de kapsam dâhilinde değerlendirilmiştir).

\section{Alanyazın Tarama Stratejisinin Belirlenmesi}

Okuma güçlüğü ile ilgili yapılan çalışmaların taranması süreci 15 Kasım 2020 ve 15 Mart 2021 tarihleri arasında gerçekleştirilmiştir. Bu kapsamda TR Dizin, ERIC, Web of Science, YÖK Ulusal Tez Merkezi, YÖK Akademik, DERGIPARK, Google Akademik ve SOBIAD veri tabanlarında tarama yapılmıştır. Veri tabanlarında yapılan taramalarda "okuma güçlüğü", "okuma bozukluğu", "okuma problemi”, "disleksi”, "dislektik", "öğrenme güçlüğü", "özgül öğrenme güçlüğü", "özel öğrenme güçlüğü", "zayıf okuyucular" ve "okuma zorluğu" anahtar kelimeleri ve bu kelimelerin İngilizce karşıııları kullanılmıştır. Sistematik derleme çalışmalarında konu ile ilgili yapılan tüm çalışmalara ulaşıımasının önemli olması ve gözden kaçırılan çalışmalar nedeniyle bir sınırlıık oluşmasına engel olmak için tarama işlemi iki araştırmacı tarafından ayrı ayrı yapılmış ve veri tabanları haricinde çeşitli arama motorlarında manuel aramalar gerçekleştirilmiştir. Alanyazın taraması sürecinde ulaşılan çalışma sayılarına ilişkin veri tabanı- anahtar kelime bazındaki veriler Tablo 1'de gösterilmektedir.

Tablo 1.

Alanyazın Taraması Sonucunda Ulaşılan Çalışma Sayıları (Veri Tabanı-Anahtar Kelime)

\begin{tabular}{|c|c|c|c|c|c|c|c|c|}
\hline $\begin{array}{l}\text { Anahtar } \\
\text { Kelimeler }\end{array}$ & $\begin{array}{l}\text { TR } \\
\text { DiZiN }\end{array}$ & ERIC & $\begin{array}{l}\text { YÖK } \\
\text { Ulusal Tez } \\
\text { Merkezi }\end{array}$ & $\begin{array}{l}\text { YÖK } \\
\text { Akademik }\end{array}$ & $\begin{array}{l}\text { DERGi } \\
\text { PARK }\end{array}$ & $\begin{array}{l}\text { Google } \\
\text { Akademik }\end{array}$ & SOBIAD & $\begin{array}{l}\text { Web of } \\
\text { Science }\end{array}$ \\
\hline $\begin{array}{l}\text { okuma } \\
\text { güçlüğüu/ } \\
\text { reading } \\
\text { disability }\end{array}$ & 35 & 59 & 62 & 35 & 55 & 734 & 24 & 547 \\
\hline $\begin{array}{l}\text { okuma } \\
\text { bozukluğu/ } \\
\text { reading } \\
\text { disorder/ }\end{array}$ & 5 & 1 & 3 & 3 & 8 & 236 & 0 & 341 \\
\hline
\end{tabular}




\begin{tabular}{|c|c|c|c|c|c|c|c|c|}
\hline $\begin{array}{l}\text { okuma } \\
\text { problemi }\end{array}$ & 5 & - & 4 & 0 & 5 & 138 & 1 & - \\
\hline $\begin{array}{l}\text { disleksi/ } \\
\text { dyslexia }\end{array}$ & 18 & 138 & 43 & 22 & 40 & 548 & 17 & 3 \\
\hline $\begin{array}{l}\text { dişlektik/ } \\
\text { dyslexic/ } \\
\text { dyslectic }\end{array}$ & 1 & 45 & 5 & 2 & 3 & 103 & 1 & 0 \\
\hline $\begin{array}{l}\text { öğrenme } \\
\text { güçlüğü/ } \\
\text { learning } \\
\text { disability }\end{array}$ & 145 & 724 & 340 & 138 & 187 & 986 & 71 & 1057 \\
\hline $\begin{array}{l}\text { özgül } \\
\text { öğrenme } \\
\text { güçlüğü/ } \\
\text { specific } \\
\text { learning } \\
\text { disability }\end{array}$ & 22 & 76 & 89 & 24 & 14 & 350 & 6 & 43 \\
\hline $\begin{array}{l}\text { özel } \\
\text { öğrenme } \\
\text { güçlüğü }\end{array}$ & 19 & - & 69 & 34 & 32 & 605 & 15 & - \\
\hline $\begin{array}{l}\text { zayıf } \\
\text { okuyucular } \\
\text { /poor } \\
\text { readers }\end{array}$ & 3 & 27 & 5 & 1 & 2 & 124 & 1 & 221 \\
\hline $\begin{array}{l}\text { okuma } \\
\text { zorluğu }\end{array}$ & 2 & - & 3 & 0 & 4 & 193 & 0 & - \\
\hline Toplam & 255 & 1070 & 623 & 259 & 350 & 4017 & 136 & 2212 \\
\hline
\end{tabular}

\section{Alanyazın Taraması ve Dâhil Edilebilecek Potansiyel Çalışmaların Belirlenmesi}

Alanyazın taramasında veri tabanlarının gelişmiş arama seçenekleri kullanılarak anahtar kelimeler, yayın yılı ve çalışma alanı gibi kriterler belirlenerek başık ve anahtar kelime aramaları yapılmıştır. Veri tabanı taramaları sonucunda toplam 8922 sonuç elde edilmiştir. Öncelikle farklı veri tabanlarında birlikte taranan birbirinin aynısı olan çalışmalar belirlenmiş ve 1426 araştırma çıkarıldıktan sonra kalan 7496 araştırma başlıklarına göre incelenmiştir. Başlıklarına göre yapılan inceleme sonucunda ise eğitim bilimleri alanında yapılmadığı tespit edilen 4037 araştırma dışarıda tutulmuştur. Sonraki aşamada, kalan 3459 çalışma özetlerine göre incelenmiştir. Özet incelemeleri sonrasında yöntem bakımından (müdahale uygulaması içermeyen) 904, sınıf düzeyi bakımından (ilkokul düzeyinde olmayan) 1277, örneklem bakımından (Türk olmayan katılımcılar) 863 araştırma dâhil etme kriterlerine uymadığı için kapsam dışı bırakılmıştır. Tarama sürecine ait akış şeması Şekil 1'de gösterilmektedir. 
Türkiye'de Okuma Güçlüğünü Gidermeye Odaklanan İlkokul Düzeyindeki Araştırmaların İncelenmesi: 2000 2020 Dönemi

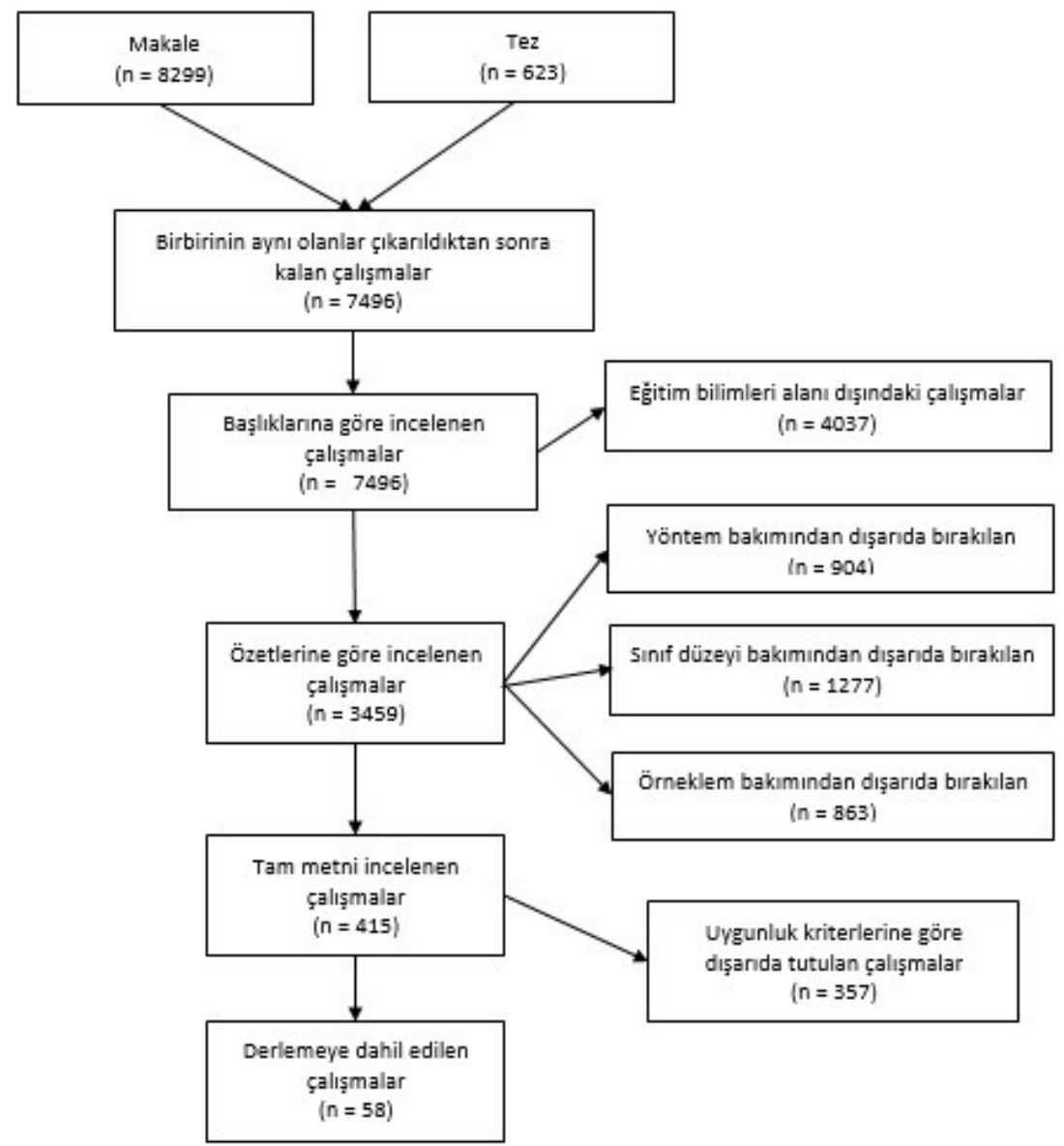

Şekil 1. Alanyazın Tarama Süreci

\section{Dâhil Edilen Çalışmaların Tanımlaması ve Değerlendirilmesi}

Başlık ve özetlere göre yapılan değerlendirmelerden sonra kalan 415 araştırmanın tam metinleri, dâhil etme ve dışarıda bırakma kurallarına göre ayrıntılı bir şekilde incelenmiş 357 araştırma daha dışarıda tutularak 58 araştırmanın analiz aşamasına geçilmiştir. Bu aşamaların tamamı iki araştırmacı tarafından ayrı ayrı yapıımış ve araştırmacılar arasında \%100 uzlaşma sağlanana dek araştırmalar gözden geçirilmiştir.

\section{Araştırma Bulgularını Analiz Etme ve Sentezleme}

Belirlenen 58 çalışma bir şablon kullanılarak analiz edilmiştir. Bu şablon incelenen çalışmalara ait; yazarlar, yöntem, araştırma deseni, katılımcı özellikleri, sınıf düzeyi, örneklem büyüklüğü, cinsiyet, okuma problemlerinin tanımlanması, okuma problemlerinin tanımlanma süreci, okuma becerilerini ölçme araçları, müdahale uygulamaları, müdahale uygulamalarının süresi ve müdahale uygulamalarının sonuçları/ etkileri başlıklarından oluşmaktadır. Verilerin analizinde betimsel analiz ve içerik (tümevarımsal) analizi yaklaşımları birlikte kullanılmıştır. Yayın yılı, araştırma türü, yöntem, desen, veri toplama araçları, sınıf düzeyi, cinsiyet, katılımcı sayısı, okuma problemleri, okuma problemlerinin belirlenmesi ve müdahale uygulamalarının süresi boyutları için betimsel; katılımcıların bilişsel-sosyal-duygusal özellikleri ve müdahale uygulamalarının sonuçları/ etkileri boyutları için tümevarımsal içerik analizi yaklaşımı benimsenmiştir.

\section{Geçerlik ve Güvenirlik}

Derleme çalışmalarında geçerlik ve güvenirliği sağlamada en önemli iki faktörün başarılı bir alanyazın tarama süreci ve belirlenen çalışmaların ayrıntılı bir şekilde analiz edilmesi olduğu düşünülmektedir. Bu araştırmanın geçerliğini ve güvenirliğini sağlamak için detaylı bir alanyazın tarama süreci gerçekleştirilmiştir. Sistematik aşamaları içeren alanyazın tarama süreci iki araştırmacı 
tarafından ayrı ayrı yapılmış ve süreç, araştırmacılar arasında \%100 uyum sağlanana kadar yinelenmiştir. Ayrıca anahtar kelimelerle yapılan alanyazın taramasında oluşabilecek muhtemel problemlerin önüne geçmek için ek olarak manuel taramalar gerçekleştirilmiştir. Belirlenen çalışmaların analizinde ise iki araştırmacının birbirinden bağımsız incelediği araştırma verileri ortak bir şablona işlenmiştir. Ortak bir şablonun kullanılması, analize tabi olacak boyutların belirlenmesi ve veri analizi sürecinin her bir aşamasının iki araştırmacı tarafından ayrı ayrı gerçekleştirilmesinin bu araştırmanın geçerliği ve güvenirliğine katkı sağladığı söylenebilir.

\section{Araştırma ve Yayın Etiği}

Bu çalışmada "Yükseköğretim Kurumları Bilimsel Araştırma ve Yayın Etiği Yönergesi" kapsamında uyulması belirtilen tüm kurallara uyulmuştur. Yönergenin ikinci bölümü olan "Bilimsel Araştırma ve Yayın Etiğine Aykırı Eylemler" başlığı altında belirtilen eylemlerden hiçbiri gerçekleştirilmemiştir.

\section{Etik Kurul Izni}

Kurul adı = Ondokuz Mayıs Üniversitesi Sosyal ve Beşerî Bilimler Etik Kurulu

Karar tarihi $=26.03 .2021$

Belge sayı numarası $=2021 / 265$

\section{Bulgular}

Bu bölümde 2000-2020 yılları arasında yayınlanan ve okuma güçlüğünün giderilmesini amaçlayan ilkokul düzeyindeki araştırmalardan elde edilen bulgular sunulmuştur. Bulgular araştırmaların genel özellikleri (yayın yılı, araştırma türü, yöntem, desen, veri toplama araçları), araştırmalardaki katılımcıların özellikleri (sınıf düzeyi, cinsiyet, katılımcı sayısı, okuma problemleri, okuma problemlerinin belirlenmesi, bilişsel-sosyal-duygusal özellikleri) ve müdahale uygulamalarının özellikleri (müdahale uygulamaları, müdahale uygulamalarının süresi, etkileri ve sonuçları) başlıkları altında sunulmuştur.

\section{Araştırmaların Genel Özellikleri}

Incelenen araştırmaların özellikleri; yayın yılı, araştırma türü, yöntem, desen ve veri toplama araçları olmak üzere alt başlıklar halinde sunulmuştur.

\section{Yayın Yılı}

Bu çalışma kapsamında 2000-2020 yılları arasında yayınlanan araştırmalar incelenmiştir. Araştırmaların yıllara göre dağılımı Şekil 2'de gösterilmektedir.

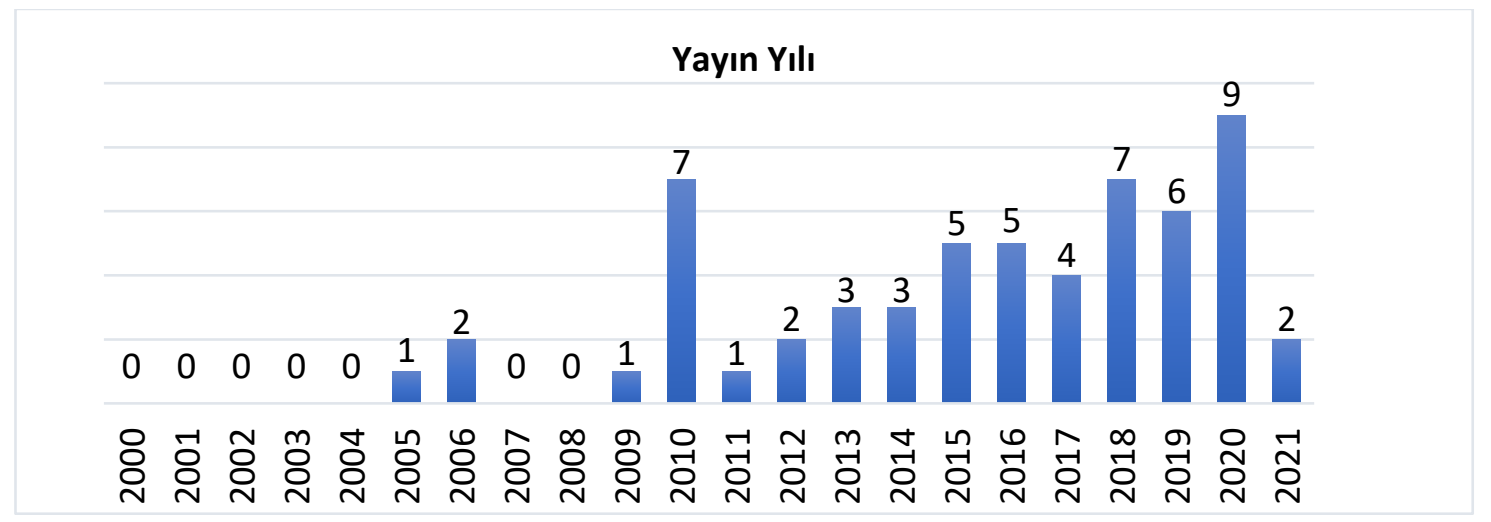

Şekil 2. Yayın Yılı

Şekil 2'ye göre araştırmaların çoğunlukla son on yılda gerçekleştirildiği görülmektedir. Ayrıca; iki çalışma (Akyol ve Sural Çoban, 2021 ve Başar, Göncü ve Baran, 2021) 2021 yılında yayınlanmıştır. 
Türkiye'de Okuma Güçlüğünü Gidermeye Odaklanan İlkokul Düzeyindeki Araştırmaların İncelenmesi: 20002020 Dönemi

Ancak 2020 yılında erken görünümde yayınlandığı ve bu çalışmalara 2020 yılı içerisinde erişilebildiği için bu çalışmalar da araştırmaya dâhil edilmiştir.

\section{Araştırma Türü}

İncelenen araştırmaların türleri Şekil 3'te gösterilmektedir.

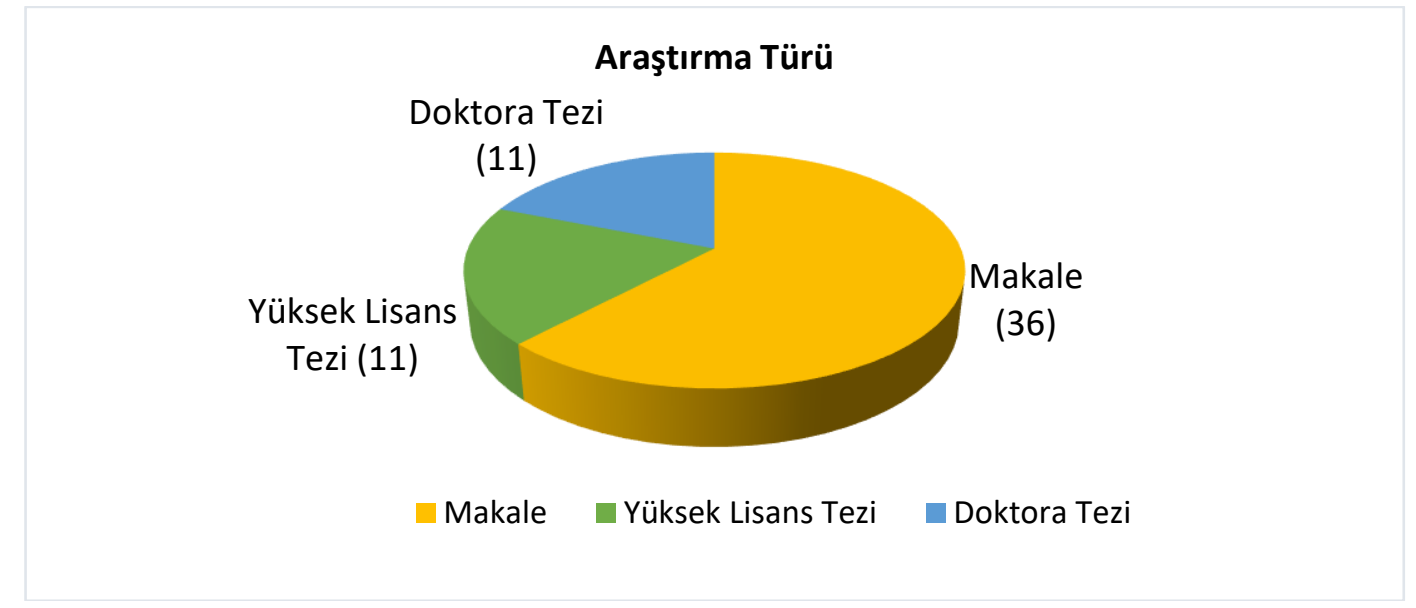

Şekil 3. Araştırma Türü

Şekil 3’te görüldüğü gibi incelenen okuma güçlüğü çalışmalarının \%62'sini makaleler, \%19'unu doktora tezleri ve \%19’unu yüksek lisans tezleri oluşturmaktadır.

\section{Yöntem}

İncelenen araştırmalarda nitel ve nicel yöntemlerin benimsendiği görülmektedir. Araştırmaların yöntemlerine göre dağılımı Şekil 4'te gösterilmektedir.

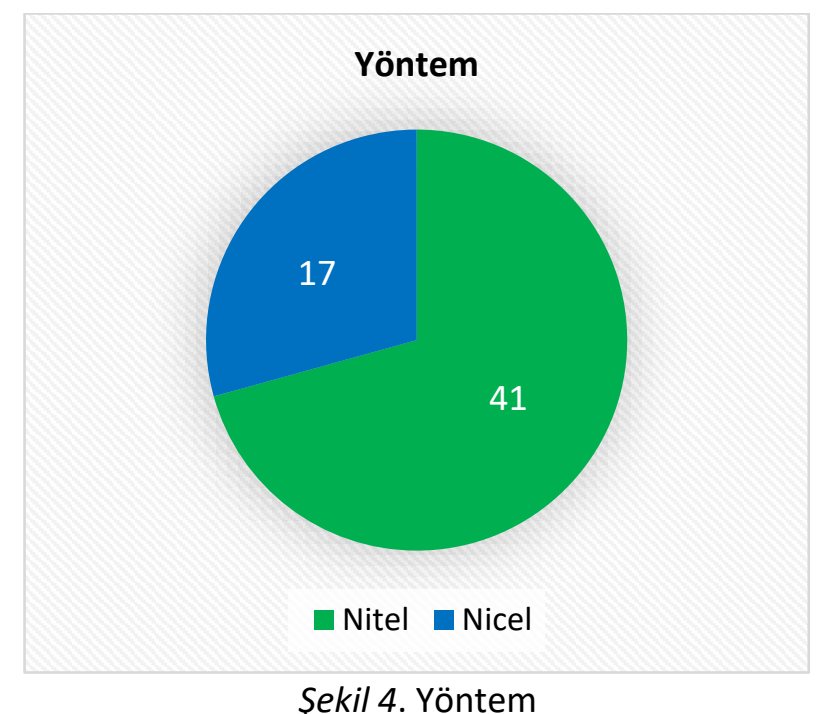

Şekil 4'e göre incelenen 58 araştırmanın 41'inin $(\% 70,7)$ nitel, 17'sinin $(\% 29,3)$ ise nicel yöntemler esas alınarak gerçekleştirildiği görülmektedir.

\section{Desen}

Incelenen araştırmaların desenine ilişkin bulgular Şekil 5'te gösterilmektedir. 


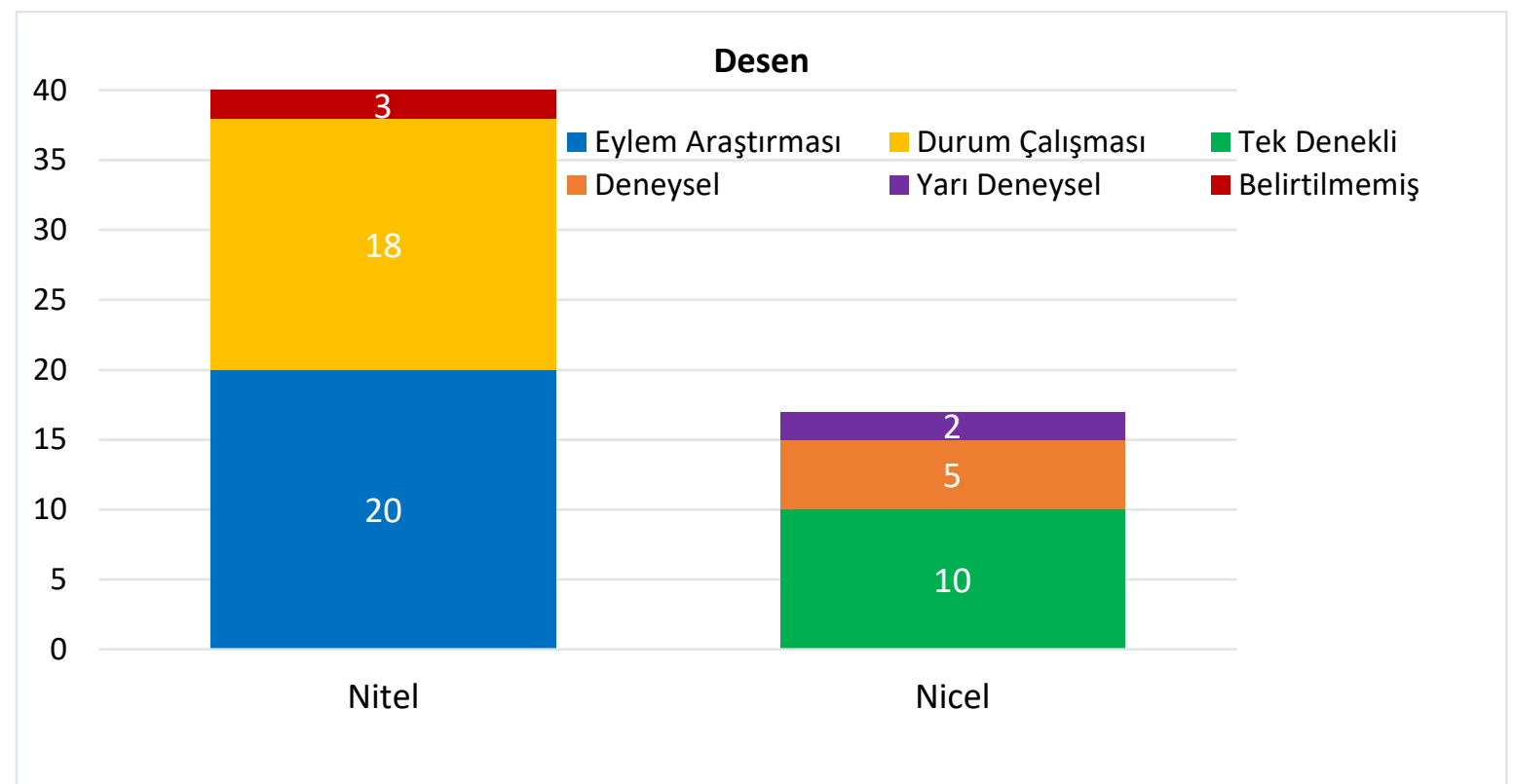

Şekil 5. Desen

Şekil 5'te görüldüğü gibi incelenen araştırmalarda en çok eylem araştırması kullanılmıştır. Eylem araştırmasını yine nitel paradigmaya ait olan durum çalışması deseni takip etmektedir. Nicel araştırmalarda ise çoğunlukla tek denekli araştırma deseninin kullanıldığı görülmektedir.

\section{Veri Toplama Araçları}

Çalışma kapsamında incelenen 58 araştırmada veri toplama aracı olarak ifade edilen ölçme araçları Tablo 2'de gösterilmektedir.

Tablo 2.

Veri Toplama Araçları

\begin{tabular}{ll}
\hline Yazar(lar) & Veri Toplama Araçları \\
\hline Akın, 2020 & Okuma Hızı ve Hatası Veri Toplama Aracı, Prozodik Okuma Düzey \\
& Belirleme Aracı, Okuduğunu Anlama Veri Toplama Aracı \\
Aktepe ve Akyol, 2015 & Yanlış Analizi Envanteri \\
Akyol ve Boyacı Altınay, 2019 & Yanlıs Analizi Envanteri \\
Akyol ve Çoban Sural, 2021 & Yanlış Analizi Envanteri, Okuma Motivasyonu Profili Ölçeği, Ses ve \\
& Video Kayıtları
\end{tabular}

Akyol ve Ketenoğlu Kayabaşı, Yanlış Analizi Envanteri, Okuma Metinleri, Okuma Metinleri Ses 2018 Kayıtları, Araştırma Günlükleri ve Gözlemleri

Akyol ve Kodan, 2016 Yanlış Analizi Envanteri, Hikâye Edici Metinler, Ses Kayıtları

Akyol ve Sever, 2019 Yanlış Analizi Envanteri, Kopyalama ve Dikte Metinleri, Çok Boyutlu

Akyol ve Yıldız, 2010 Okunaklılık Ölçeği, Görüşme

Atmaca, 2020 Harf listesi, Kelime listesi, Heceleme Listesi, Okuma Metinleri, Yazı Görevleri

Demografik Bilgi Formu, Formel Olmayan Okuma Envanteri, İşittiğini Yazma Testi, Gördügünü Yazma Testi, Çocuk Görüşme Formu, Öğretmen Görüşme Formu

Balcı ve Çayır, 2017 Harf Listesi, Hece Listesi, Kelime Listesi, Okuma Metinleri, Yanlış Analizi Envanteri

Balıkçı, 2020 Sesli Okuma Becerisi ve Okuduğunu Anlama Testi-II (SOBAT-II), Türkçe Okul Çağı Dil Gelişim Testi (TODiL), Türkçe 'de Kelime Okuma 
Türkiye'de Okuma Güçlüğünü Gidermeye Odaklanan Illkokul Düzeyindeki Araştırmaların İncelenmesi: 20002020 Dönemi

Bilgisi Testi (KEOT), Okuma Motivasyonu Ölçeği, Okuma Tutum Ölçeği, Anadolu-Sak Zekâ Ölçeği (ASis)

Başar, Göncü ve Baran, 2021 Gözlem Formu, Yanlış Analizi Envanteri, Çok Boyutlu Okunaklılık Ölçeği

Baştuğ ve Öncü, 2020 Gözlem Notları, Görüşme, Program Tabanlı Ölçme (Doğru Okuma, Okuma Hızı ve Kelime Tanıma Yüzdesi)

Çayır ve Balcı, 2017 Gözlem, Görüşme, Doküman Analizi, Yanlış Analizi Envanteri, Harf Listesi, Kelime Listesi, Okuma Metinleri

Çeliktürk Sezgin ve Akyol, Yanlış Analizi Envanteri

2015

Dağ, 2010

Yanlış Analizi Envanteri

Dağlı Gökbulut, Akçamete ve

Okuduğunu Anlama Becerileri İzlem Çizelgesi

Güneyli, 2020

Dinç, 2017

Harf Listesi, Kelime Listesi, Heceleme Listesi, Okuma Metinleri, Yazı Görevleri

Doğuyurt ve Doğuyurt, 2016

Duran ve Sezgin, 2012a

Duran ve Sezgin, 2012b

Dündar ve Akyol, 2014

Ege, 2019

Yanlış Analizi Envanteri

Yanlış Analizi Envanteri, Okuma Metinleri, Öğrencinin Metin Okuma Ses Kayıtları

Yanlış Analizi Envanteri, Okuma Metinleri, Öğrencinin Metin Okuma Ses Kayıtları

Yanlış Analizi Envanteri

Yanlış Analizi Envanteri, Okuduğunu Anlama Envanteri, Metinler

Ekiz, Erdoğan ve Uzuner, Günlük, Gözlem, Yanlış Analizi Envanteri

2011

Görgün, 2018

Öğrenme Güçlüğü Belirti Tarama Listesi Öğretmen ve Anne- Baba Formu, Sesli Okuma Becerisi ve Okuduğunu Anlama Testi (SOBAT), Anadolu- Sak Zekâ Ölçeği (ASiS), Uygulamacı Değerlendirme Formu

Gül, 2019

Gürbüz, 2015

ilter, 2018

Karasakaloğlu ve Saraçlı

Çelik, 2018

Kardaş İşler ve Şahin, 2016

Kaşdemir, 2020

Marmara Öğrenme Stilleri Ölçeği, Yanlış Analizi Envanteri, Kelime Kutusu Stratejisi, Hikâye Haritası Yöntemi

Yanlış Analizi Envanteri

Okuduğunu Anlama Değerlendirme Aracı

Dinlediğini Anlama Ölçeği, Yanlış Analizi Envanteri, Metinler, Okuduğunu Anlama Ölçeği

Metinler ve Anlama Soruları

Yanlış Analizi Envanteri, Resimli Öyküleyici Metinler, Şematik Düzenleyici, Hikâye Haritası, Karakter Ağı, Zaman Çizelgesi, Özet Çerçeve, Maze Tekniği

Kodan, 2015

Kuruyer, 2014

Yanlış Analizi Envanteri, Okuduğunu Anlama Envanteri, Alan Notları Okuma Güçlüğü Tanılama Envanteri, Okuduğunu Anlama Envanteri, Okuma Motivasyon Ölçeği, Okuma Motivasyon Profili- Türkçe Form, Stroop Testi TBAG Formu, Görsel İşitsel Sayı Dizileri Testi-B Formu, Sayı Dizileri Öğrenme Testi, İşaretleme Testi, Siemens MAGNETOM Trio Manyetik Rezonans Görüntüleme Cihazı, Alan Notları, Gözlem Formları

Okur ve Öztürk, 2018

Yanlış Analizi Envanteri

Özbek, 2014

Performans Kayıt Tabloları, Uygulama Güvenirliği Formları, Gözlemci Güvenirliği Formu, Okuma Metinleri

Özdemir, 2013

Marmara Öğrenme Stilleri Ölçeği, Yanlış Analizi Envanteri, Kelime Kutusu Stratejisi

Özkara, 2010

Kişisel Bilgi Formu, Kelime Anlama Düzey ve Yüzdeliğini Belirleme Kılavuzu 
Peksoy, 2018

Sağlam, 2019

Sert, 2019

Sidekli, 2010a

Sidekli, 2010b

Sidekli ve Yangın, 2005

Sirem, 2020

Sözen, 2017

Şahin ve Baştuğ, 2020

Şahin ve Çakır, 2018

Taşkaya, 2010

Türkmenoğlu, 2016

Ulu ve Akyol, 2016

Ulu ve Başaran, 2013

Urfalıoğlu Eroğlu, 2020

Uzunkol, 2013

Yamaç, 2015

Yangın ve Sidekli, 2006

Yılmaz, 2006

Yücel, 2009
Metinler ve Anlama Soruları, Hata Analiz Envanteri, Prozodik Okuma Ölçeği

Yanlış Analizi Envanteri

Metinler, Prozodik Okuma Ölçeği, Sosyal Geçerlik Formları

Aile Bilgi Formu, Öğretmen Bilgi Formu, Wisc-r Zekâ Testi, Sesli Okuma Hatalarını Belirleme Ölçeği, Okuduğunu Anlama Testi

Okuma Hataları Rubriği, Metinler

Kişisel Değerlendirme Formu, Ortam ve Seslendirme Ölçeği

Yanlış Analiz Envanteri, Okuma Motivasyonu Ölçeği, Okumaya Yönelik Tutum Ölçeği, Çalışma Grubuna İlişkin Bilgi Formu, Okuma Güçlüğü Belirleme Öğretmen Tespit Formu

Yanlış Analizi Envanteri, Gözlem (Kamera) Kayıtları, Yansıtıcı Günlük, Sağılık Kontrol Testleri, Öğrenci Çalışma Örnekleri, Yarı Yapılandırılmış Görüşme, Okuduğunu Anlama Testi

Hikâye Edici Okuma Metinleri, Yanlış Analizi Envanteri, Gözlem Notları, Hızlı Kelime Tanıma Tabloları, Ses Kayıtları

Okuma- Yazma Beceri Rubriği, Okuma Hızı Ölçümü, Yazma Hızı Ölçümü, Öğretmen Görüşleri

Yanlış Analizi Envanteri

Yanlış Analizi Envanteri, Prozodik Okuma Ölçeği, Çalışma Metinleri, Görüşme Formları, Alan Notları, Araştırma Günlüğü, Ses Kayıtları

Yanlış Analizi Envanteri

Yanlış Analizi Envanteri, Okunan Metne İlişkin Tutumu Belirleme Ölçeği

TILLS Testi

Yanlış Analizi Envanteri, Video Kayıtları

Yanlış Analizi Envanteri, Prozodik Okuma Ölçeği, Okuma Hızı Ölçümü Kişisel Değerlendirme Formu, Ortam ve Seslendirme Ölçeği

Hata Analizi Envanteri

Sözcük Okuma ve Okuma Hızı Ölçümleri, Dile Bağıı Okuma Güçlüğünün Erken Tanımlanması Kontrol Listesi, Genel İşitsel Süreç Becerileri Kontrol Listesi, Çocuk Illetişim Kontrol Listesi, Ankara Artikülasyon Testi, Sesbilgisel Farkındalık Becerileri Değerlendirme Aracı Yanlış Analizi Envanteri

Tablo 2'ye göre araştırmaların çoğunda kullanılan veri toplama aracının "Yanlış/ Hata Analizi Envanteri" olduğu görülmektedir. Genel itibariyle incelendiğinde ise araştırmaların büyük çoğunluğunda performans temelli ölçme uygulamalarının yapıldığı görülmektedir. Ölçme araçlarının isimleri farklı olarak ifade edilse de araştırmalarda akıcı okuma (okuma hızı, kelime tanıma vb.) ve okuduğunu anlama becerilerinin performans temelli işlemlerle ölçüldüğü görülmektedir.

\section{Katılımcıların Özellikleri}

Incelenen araştırmalardaki katılımcıların özellikleri; sınıf düzeyi, katılımcı sayısı, cinsiyet, okuma problemleri, okuma problemlerinin belirlenmesi ve bilişsel-sosyal-duygusal özellikler olmak üzere alt başlıklar halinde sunulmuştur.

\section{Sınıf Düzeyi}

Katılımcıların sınıf düzeylerine ilişkin bulgular Şekil 6' da gösterilmektedir. 
Türkiye'de Okuma Güçlüğünü Gidermeye Odaklanan İlkokul Düzeyindeki Araştırmaların İncelenmesi: 20002020 Dönemi

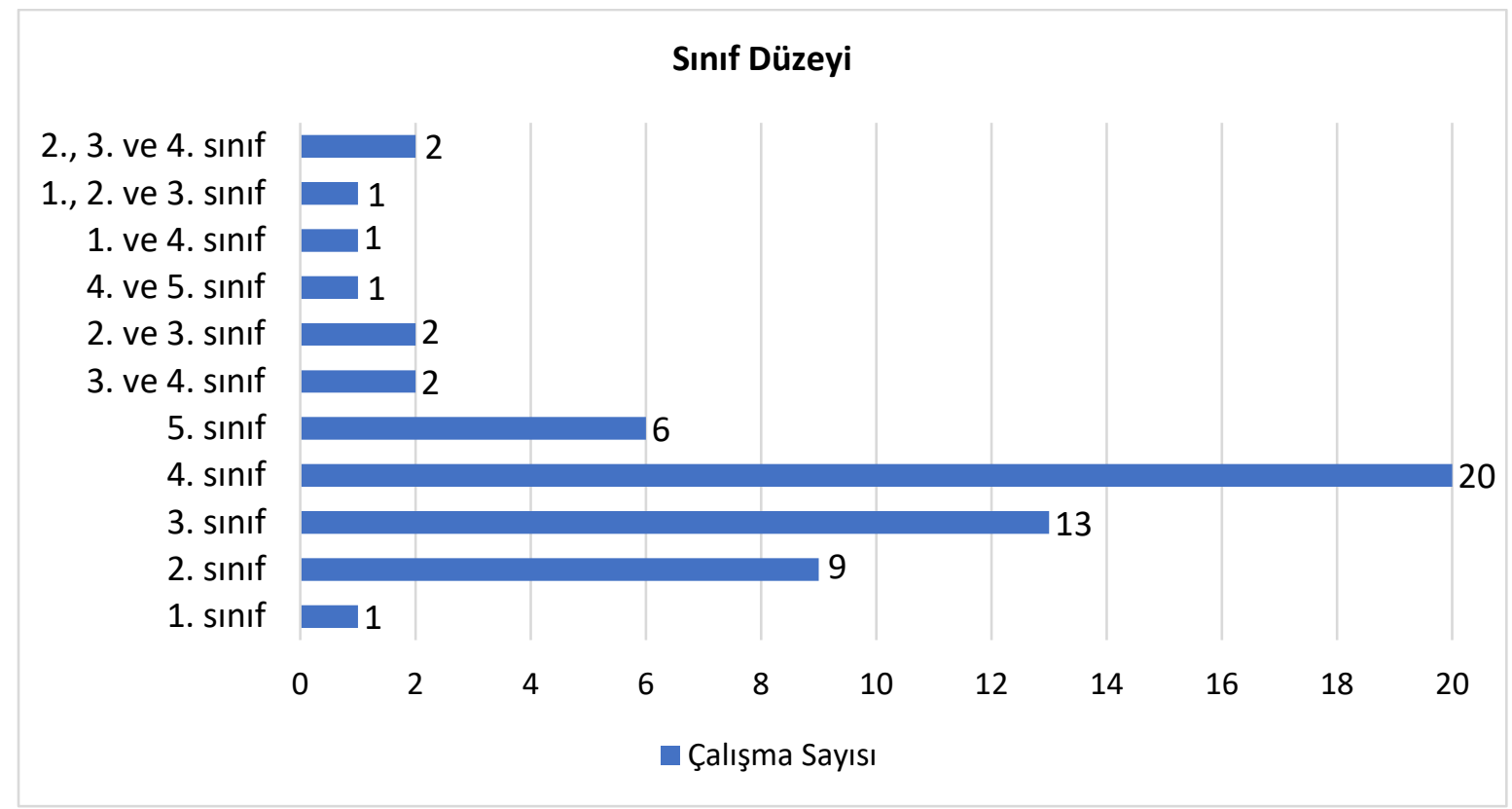

Şekil 6. Sınıf Düzeyi

Şekil 6 incelendiğinde; 58 araştırmanın 49'unun (\%84,5) katılımcı grubunu yalnızca bir sınıf düzeyindeki öğrencilerin oluşturduğu görülmektedir. 9 araştırmanın $(\% 15,5)$ ise birden fazla sınıf düzeyindeki öğrencilerle yürütüldüğü görülmektedir. Sınıf düzeylerine göre bakıldığında ise en fazla dördüncü sınıf öğrencileri (\%34,5) ile yapılan çalışmaların olduğu görülmektedir. Bunu sırasıyla üçüncü $(\% 22,4)$, ikinci $(\% 15,5)$ ve beşinci sınıf $(\% 10,3)$ öğrencileri takip etmektedir.

\section{Katılımcı Sayısı/Örneklem}

Araştırmalardaki katılımcı/ örneklem sayılarına ilişkin bilgiler Şekil 7'de gösterilmektedir.

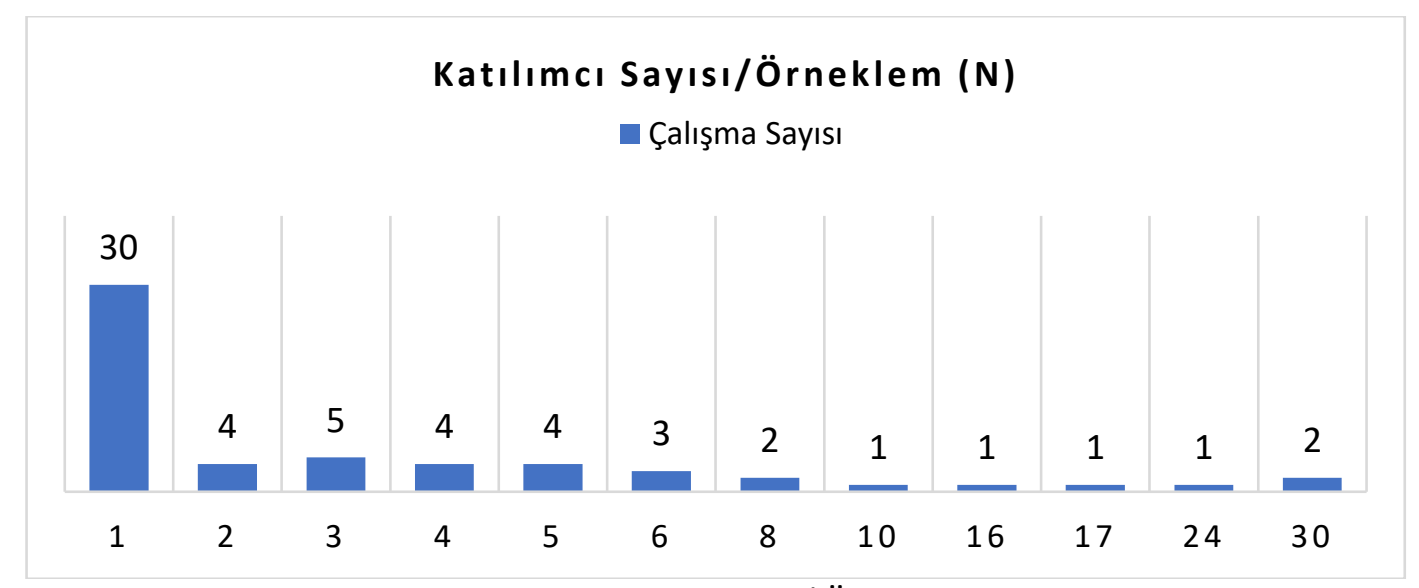

Şekil 7. Katılımcı Sayısı/ Örneklem

Şekil 7'ye göre incelenen 58 araştırmadan 30'unun $(\% 51,7)$ tek katılımcıyla yürütüldüğü görülmektedir. Genele bakıldığında ise çalışmaların yaklaşık \%90'ının 8 veya daha az katılımcı ile gerçekleştirildiği söylenebilir. Bazı araştırmalar okuma güçlüğü yaşayan öğrenciler ve normal gelişim gösteren öğrencilerle birlikte yürütülmüştür. Şekil 7'de verilen katılımcı sayıları araştırmalardaki yalnızca öğrenme güçlüğü yaşayan öğrencilerin sayılarıdır.

\section{Cinsiyet}

Incelenen 58 araştırmadan 30'unun tek katılımcılı araştırma olduğu, 28 araştırmanın ise birden fazla katıımcıyla yürütüldüğü görülmektedir. Tek katılımcılı araştırmalardaki katılımcıların cinsiyet 
dağılımının erkek ve kız olarak sınıflandırabildiği; çok katılımcılı araştırmaların çoğunda ise erkek ve kız katılımcıların birlikte araştırmaya dâhil edildiği görülmektedir. Dolayısıyla araştırmalardaki katılımcıların cinsiyetleri genel olarak incelenmiş, ardından tek katılımcılı ve çok katılımcılı araştırmalardaki cinsiyet durumları ayrıca analiz edilmiştir. Tek katılımcılı araştırmaların 11'inde erkekler, altısında ise kızlarla çalışıldığı görülmektedir. Çok katılımcı çalışmaların ise 22'sinin erkek ve kızlarla, birinin yalnızca erkeklerle gerçekleştirildiği görülmektedir. Cinsiyet bilgisinin verildiği 39 çalışmanın toplam katııımcı sayılarına göre cinsiyet dağılımına bakıldığında ise erkek katılımcı sayısının 112, kız katılımcı sayısının ise 73 olduğu görülmektedir. Incelenen araştırmalardaki katıımcıların cinsiyetlerine ilişkin bulgular Şekil 8' de gösterilmektedir.

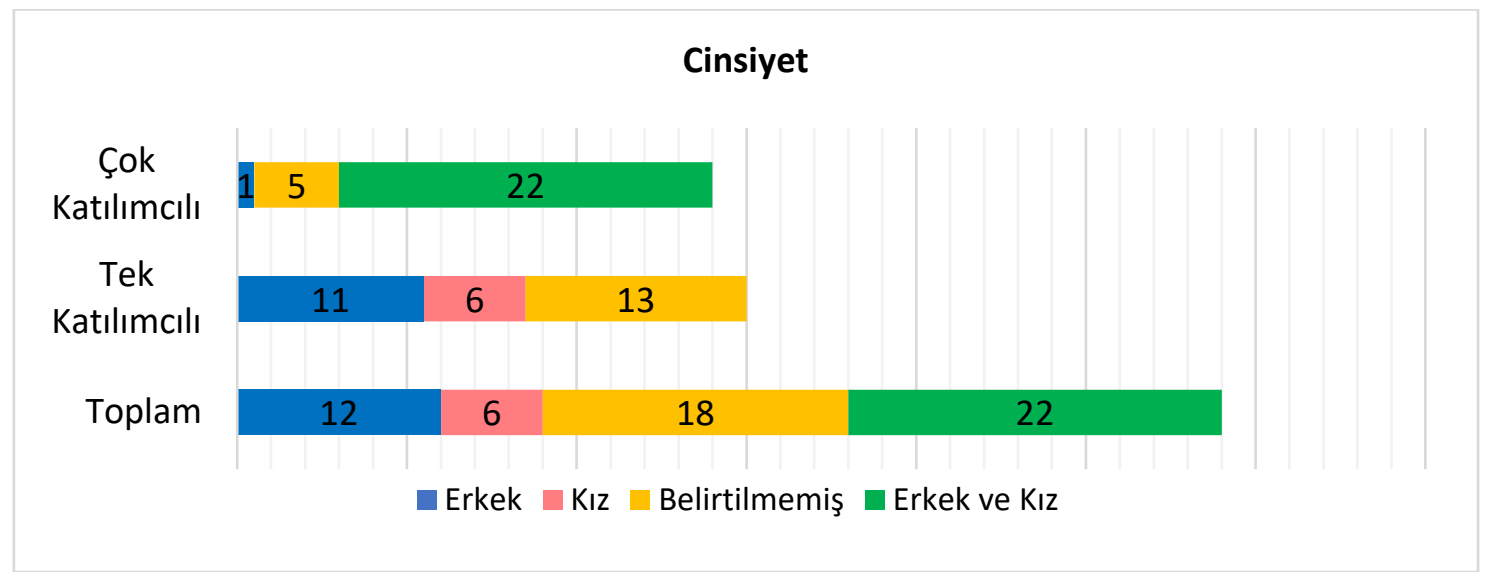

Şekil 8. Cinsiyet

\section{Okuma Problemleri}

Bu çalışmada incelenen 58 araştırmanın katılımcılarına ait ortak nokta; öğrencilerin bedensel ve zihinsel herhangi bir yetersizliği bulunmamasına rağmen okuma ile ilgili problemler yaşamalarıdır. Incelenen araştırmalarda öğrencilerin okuma problemlerinin ifade biçimlerine ilişkin bulgular şekil 9'da gösterilmektedir.

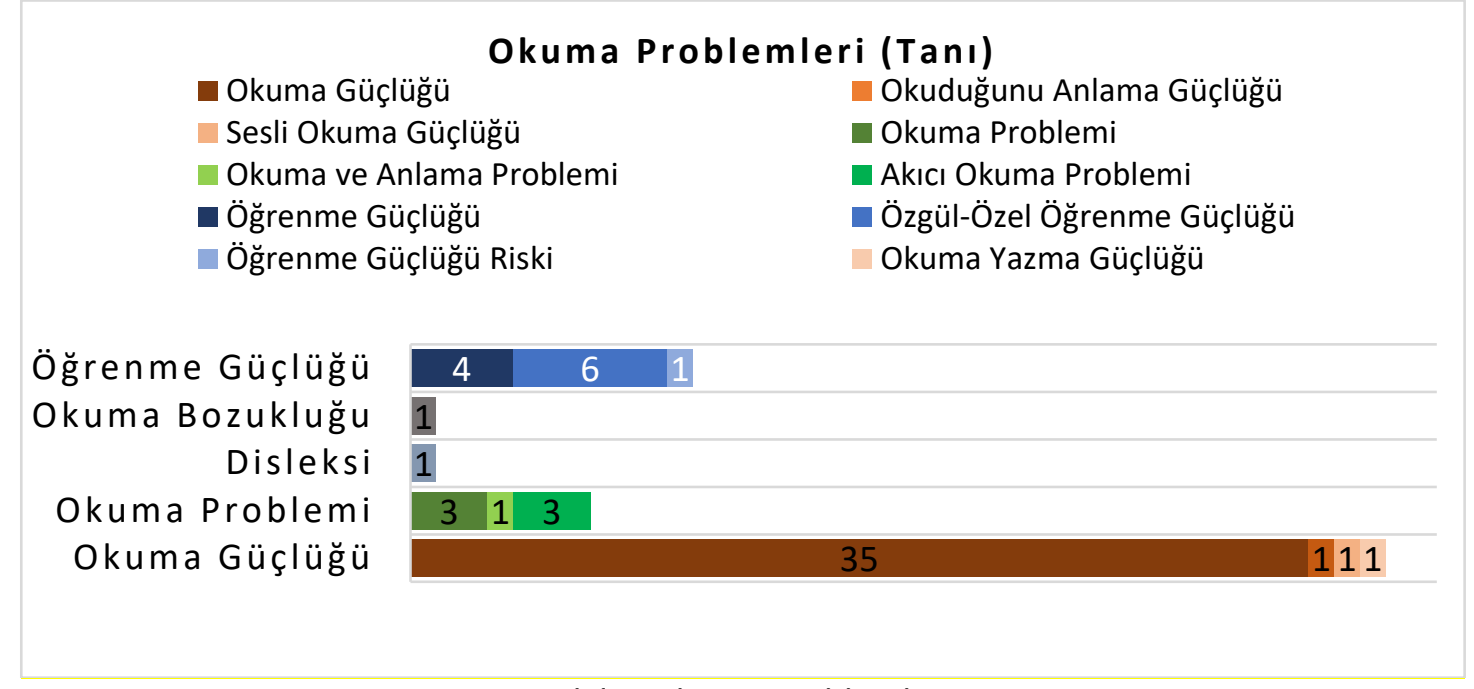

Şekil 9. Okuma Problemleri

Şekil 9'da görüldüğü gibi incelenen araştırmalarda katılımcıların okuma problemleri genel olarak okuma güçlüğü şeklinde tanımlanmaktadır. Bununla birlikte sesli okuma güçlüğü, okuma yazma güçlüğü, okuduğunu anlama güçlüğü, öğrenme güçlüğü, akıcı okuma problemi gibi tanımlamaların yapıldığı görülmektedir. 
Türkiye'de Okuma Güçlüğünü Gidermeye Odaklanan İlkokul Düzeyindeki Araştırmaların İncelenmesi: 20002020 Dönemi

\section{Okuma Problemlerinin Belirlenmesi}

Araştırmalardaki katılımcıların okuma problemlerinin nasıl tanılandığı, okuma problemlerinin ne şekilde ve hangi araçlarla belirlendiği ile ilgili bulgular Şekil 10'da gösterilmektedir.

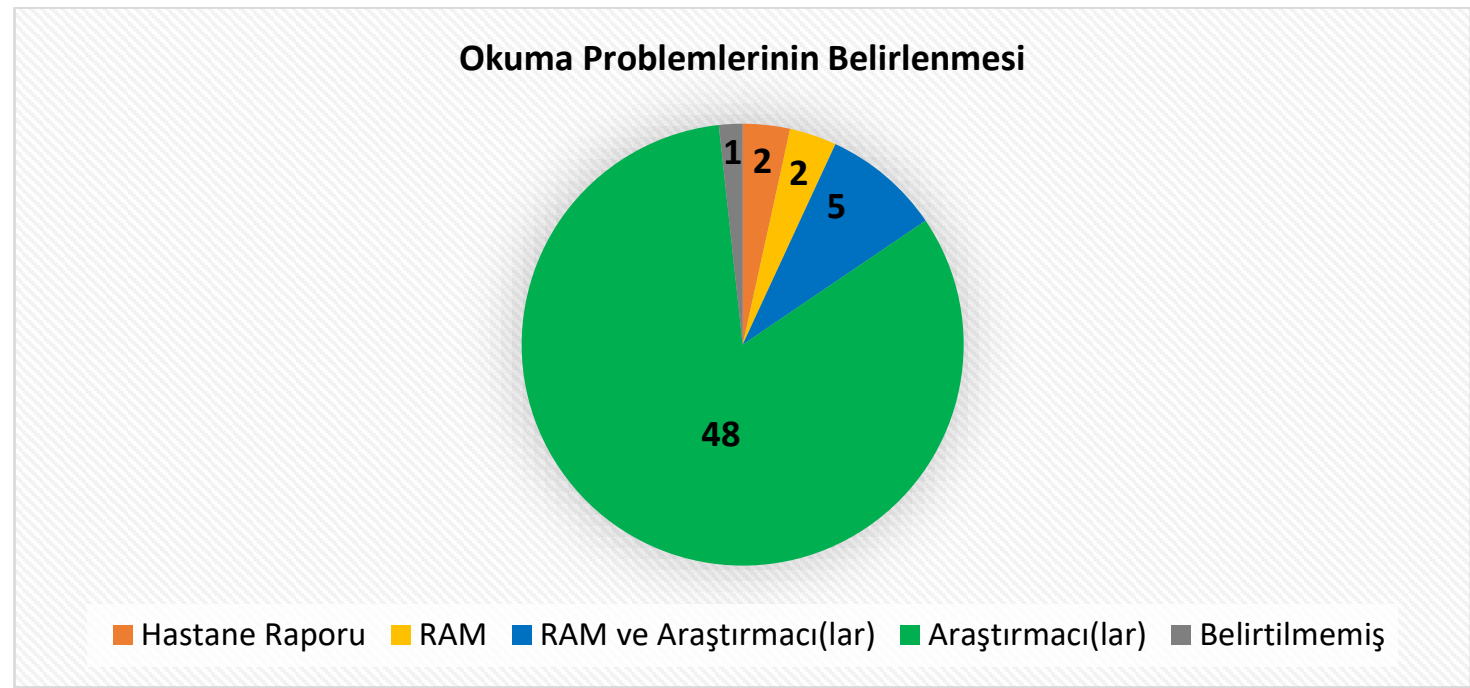

Şekil 10. Okuma Problemlerinin Belirlenmesi

Şekil 10'da görüldüğü gibi incelenen araştırmaların \%82,7'sinde katılımcıların okuma problemlerinin araştırmacılar tarafından yapılan bir takım test ya da ölçümlerle tespit edildiği görülmektedir. Diğer çalışmalarda ise öğrencilerin okuma/öğrenme problemlerinin Rehberlik Araştırma Merkezi raporları ve hastane raporlarıyla belirlendiği görülmektedir. Ayrıca 5 araştırmada da RAM raporlarıyla araştırmacılar tarafından yapılan testlerin birlikte kullanıldığı görülmektedir. Katılımcıların okuma problemlerinin araştırmacılar tarafından belirlendiği araştırmalar kendi içinde incelendiğinde ise Şekil 11'deki dağııım ortaya çıkmaktadır.

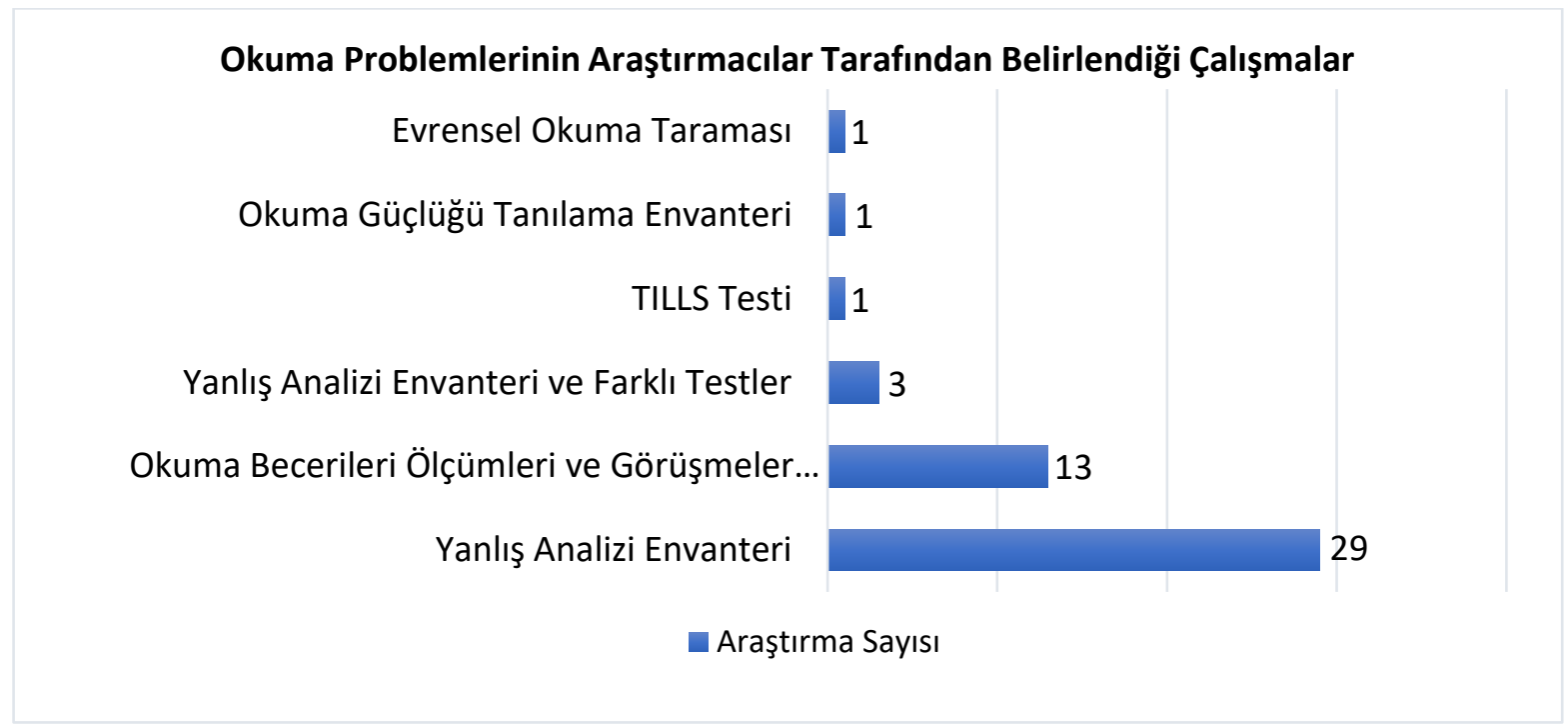

Şekil 11. Okuma Problemlerinin Araştırmacılar Tarafından Belirlendiği Çalışmalar

Katılımcıların okuma problemlerinin araştırmacılar tarafından belirlendiği 48 araştırma incelendiğinde ise araştırmaların yaklaşık \%60,4'ünde okuma problemlerinin belirlenmesinde 'Yanlış Analizi Envanteri'nin kullanıldığı görülmektedir. 13 araştırmada ise katılımcıların okuma problemlerinin kelime tanıma, okuma hızı, dakikada okunan doğru kelime sayısı, okuduğunu anlama, okuma hataları gibi çeşitli okuma becerilerinin ölçülmesiyle belirlendiği söylenebilir. Ayrıca 3 araştırmada Yanlış Analizi Envanteri ile birlikte farklı ölçümlerin de dikkate alınarak okuma problemleri olan öğrencilerin 
belirlendiği görülmektedir. Bunların dışında; öğrencilerin okuma problemlerinin belirlenmesinde Evrensel Okuma Taraması, Okuma Güçlüğü Tanılama Envanteri ve TILLS Testi'nin kullanıldığı birer araştırma da mevcuttur.

\section{Bilişsel, Duyuşsal/Duygusal ve Sosyal/ Sosyoekonomik Özellikler}

Çalışma kapsamında incelenen 58 araştırmada okuma güçlüğü yaşayan öğrencilerin ortak özellikleri Tablo 3'te gösterilmektedir.

Tablo 3.

Bilişsel, Duyuşsal/Duygusal ve Sosyal/Sosyoekonomik Özellikler

\begin{tabular}{|c|c|c|c|c|c|}
\hline $\begin{array}{l}\text { Bilişsel } \\
\text { Özellikler }\end{array}$ & $f$ & $\begin{array}{l}\text { Duyuşsal/Duygusal } \\
\text { Özellikler }\end{array}$ & $f$ & Sosyal/ Sosyoekonomik Özellikler & $f$ \\
\hline $\begin{array}{l}\text { Düşük akademik } \\
\text { başarı }\end{array}$ & 24 & Derse yönelik ilgisizlik & 25 & $\begin{array}{l}\text { Ailelerin eğitim seviyesinin düşük } \\
\text { olması (genellikle ilkokul-ortaokul } \\
\text { mezunu, bazıları okuryazar değil) }\end{array}$ & 63 \\
\hline $\begin{array}{l}\text { Dikkat ve } \\
\text { odaklanma } \\
\text { problemi }\end{array}$ & 15 & Özgüven eksikliği & 14 & $\begin{array}{l}\text { Babaların meslekleri genellikle } \\
\text { serbest meslek, işçi, çiftçi, } \\
\text { hayvancılık esnaf, şoför vb. }\end{array}$ & 53 \\
\hline $\begin{array}{l}\text { Farklı alanlarda } \\
\text { başarı } \\
\text { (matematik, fen } \\
\text { bilimleri, müzik, } \\
\text { sanat, spor, } \\
\text { drama vb.) }\end{array}$ & 8 & Hiperaktiflik & 14 & Anneler genellikle ev hanımı & 50 \\
\hline Unutkanlık & 1 & $\begin{array}{l}\text { Farklı alanlara ilgi } \\
\text { (matematik, fen, müzik, } \\
\text { sanat, spor, drama vb.) }\end{array}$ & 12 & Çok çocuklu aileler & 44 \\
\hline \multirow[t]{15}{*}{$\begin{array}{l}\text { Zaman, yer ve } \\
\text { yön sorunları }\end{array}$} & 1 & Ödev yapmak istememe & 10 & $\begin{array}{l}\text { Ailelerin ekonomik düzeyinin } \\
\text { düşük ve orta düzeyde olması }\end{array}$ & 32 \\
\hline & & Okumayı sevmeme & 8 & Arkadaşlarıyla iletişimi iyi & 26 \\
\hline & & Çekingenlik & 7 & $\begin{array}{l}\text { Kendine ait uygun çalışma } \\
\text { ortamının olmaması }\end{array}$ & 17 \\
\hline & & İçine kapanık olma & 7 & Ailenin çocukla ilgili olması & 15 \\
\hline & & $\begin{array}{l}\text { Televizyon-Çizgi } \\
\text { izlemeyi sevme }\end{array}$ & 6 & Ailenin çocukla ilgilen(e)memesi & 15 \\
\hline & & Sıkılganlık & 5 & Sık öğretmen değişikliği & 14 \\
\hline & & Okulu sevmeme & 4 & $\begin{array}{l}\text { Travma (parçalanmıs aile, aile içi } \\
\text { şiddet vb.) }\end{array}$ & 12 \\
\hline & & Utangaçlık & 3 & Arkadaşlarıyla iletişimi kötü & 10 \\
\hline & & $\begin{array}{l}\text { Bilgisayar oyunu } \\
\text { oynamaktan zevk alma }\end{array}$ & 1 & İletişim problemleri yaşama & 5 \\
\hline & & Kitap okumayı sevmeme & 1 & Kavgacılık & 4 \\
\hline & & Yazmayı sevmeme & 1 & Devamsızlık sorunu yaşama & 4 \\
\hline & & Mutsuzluk & 1 & Düşük ses tonuyla konuşma & 3 \\
\hline & & Agresiflik & 1 & Okul öncesi eğitim alma & 2 \\
\hline & & & & Okul öncesi eğitim almama & 1 \\
\hline & & & & Düzensiz yemek ve uyku saatleri & 1 \\
\hline
\end{tabular}


Tablo 3'e göre okuma güçlüğü yaşayan öğrencilerin göstermiş oldukları ortak bilişsel özelliklerin genellikle düşük akademik başarı (24) ve dikkat problemleri (15) olduğu görülmektedir. Duygusal/duyuşsal özelliklerine bakıldığında ise genellikle derse ilgisizlik (25), özgüvensizlik (14) ve hiperaktiflik (14) gibi özellikler öne çıkmaktadır. Ailelerinin eğitim seviyesinin düşük olması (63), babalarının genellikle düşük gelirli meslekler yapması (53), annelerinin ev hanımı olması (50) ve kardeş sayısının fazla olması (44) gibi özellikler ise incelenen araştırmalarda en sık ifade edilen sosyal/sosyoekonomik özelliklerdir. Öğrencilerle ilgili yukarıda ifade edilen genellemeler incelenen araştırmalarda okuma güçlüğü yaşayan çocukların betimlenmesine dayanmaktadır. Dolayısıyla yukarıda ortaya konulan öğrenci profilleri incelenen araştırmalardaki okuma problemi yaşayan öğrencilerin ortak özelliklerini göz önüne koyan bir genelleme niteliği taşımaktadır. Araştırmaların bazılarında betimlenen öğrenci profili ile benzerlik göstermeyen öğrenciler de bulunmaktadır.

\section{Müdahale Uygulamalarının Özellikleri}

İncelenen araştırmalarda okuma güçlüğünü gidermeye yönelik gerçekleştirilen uygulamaların özellikleri; müdahale uygulamaları ve uygulama süresi ve müdahale uygulamalarının sonuçları/etkileri olmak üzere alt başlıklar halinde sunulmuştur.

\section{Müdahale Uygulamaları ve Uygulama Süreleri}

Çalışma kapsamında incelenen 58 araştırmada okuma güçlügünü gidermeye yönelik gerçekleştirilen uygulamalar ve süreleri ile ilgili bulgular Tablo 4'te gösterilmektedir.

Tablo 4.

Müdahale Uygulamaları ve Uygulama Süreleri

\begin{tabular}{|c|c|c|}
\hline Yazar(lar) & Müdahale Uygulaması & Uygulama Süresi \\
\hline Akın, 2020 & $\begin{array}{l}\text { Zenginleştirilmiş Okuma Becerileri Müdahale } \\
\text { Paketi }\end{array}$ & 20 ders saati \\
\hline Aktepe ve Akyol, 2015 & Eko Okuma ve Tekrarlı Okuma & 36 saat \\
\hline $\begin{array}{l}\text { Akyol ve Boyacı Altınay, } \\
2019\end{array}$ & $\begin{array}{l}\text { Paragrafın Önceden Dinlenmesi Stratejisi, } \\
\text { Tekrarlı Okuma, Kelime Tekrarı }\end{array}$ & 38 saat \\
\hline Akyol ve Çoban Sural, 2021 & Bireyselleştirilmiş Okuma Programı & 30 ders saati \\
\hline $\begin{array}{lll}\text { Akyol ve } & \text { Ketenoğlu } \\
\text { Kayabaşı, } 2018\end{array}$ & Bireyselleştirilmiş Okuma Programı & 30 saat \\
\hline Akyol ve Kodan, 2016 & $\begin{array}{l}\text { Akıcı Okuma Stratejileri (Tekrarlı Okuma, } \\
\text { Yankılayıcı Okuma ve Eşli Okuma) }\end{array}$ & 45 ders saati \\
\hline Akyol ve Sever, 2019 & $\begin{array}{l}\text { Fernald Yöntemi, Yankılı Okuma ve Tekrarlı } \\
\text { Okuma }\end{array}$ & 60 ders saati \\
\hline Akyol ve Yıldız, 2010 & Bireyselleştirilmiş Okuma Programı & 48 saat \\
\hline Atmaca, 2020 & Bilişsel Gelişim Programı (COGENT) & 12 saat \\
\hline Balcı ve Çayır, 2017 & Çoklu Duyusal Öğrenme & 32 saat \\
\hline Balıkçı, 2020 & Okumayı Geliştirme Programı (OGEP) & 28 oturum \\
\hline $\begin{array}{l}\text { Başar, Göncü ve Baran, } \\
2021\end{array}$ & $\begin{array}{l}\text { Veli Katılımı, Seslerin Renklendirilmesi Yöntemi, } \\
\text { Eko Okuma, Tekrarlı Okuma, Eşli Okuma }\end{array}$ & 59 saat- 114 saat \\
\hline Baştuğ ve Öncü, 2020 & $\begin{array}{l}\text { Pratik Stratejilerle Erken Okuryazarlığa Yardım } \\
\text { (HELPS) }\end{array}$ & $\begin{array}{l}33 \text { oturum }(10-15 \\
\text { dk.) }\end{array}$ \\
\hline Çayır ve Balcı, 2017 & Bireyselleştirilmiş Okuma Programı & 47 ders saati \\
\hline $\begin{array}{l}\text { Çeliktürk Sezgin ve Akyol, } \\
2015\end{array}$ & $\begin{array}{l}\text { Akıcı Okuma Teknikleri (Tekrarlı Okuma, Eşli } \\
\text { Okuma, Okuyucu Tiyatroları) }\end{array}$ & 48 ders saati \\
\hline Dağ, 2010 & $\begin{array}{l}\text { 3P (Pause, Prompt, Praise) Metodu ve Boşluk } \\
\text { Tamamlama (Cloze) Tekniği }\end{array}$ & 39 ders saati \\
\hline
\end{tabular}


Dağlı Gökbulut, Akçamete Bir Öğretmen Bir Yardımcı Modeli

ve Güneyli, 2020

Dinç, 2017

Doğuyurt ve Doğuyurt,

2016

Duran ve Sezgin, 2012a

Duran ve Sezgin, 2012b

Dündar ve Akyol, 2014

Ege, 2019

Ekiz, Erdoğan ve Uzuner,

2011

Görgün, 2018

Gül, 2019

Gürbüz, 2015

ilter, 2018

Karasakaloğlu ve Saraçlı

Çelik, 2018

Kardaş İşler ve Şahin, 2016

Kaşdemir, 2020

Kodan, 2015

Kuruyer, 2014

Okur ve Öztürk, 2018

Özbek, 2014

Özdemir, 2013

Özkara, 2010

Peksoy, 2018

Sağlam, 2019

Sert, 2019

Sidekli, 2010a

Sidekli, 2010b

Sidekli ve Yangın, 2005

Sirem, 2020

Sözen, 2017

Şahin ve Baştuğ, 2020

Şahin ve Çakır, 2018

Taşkaya, 2010

Türkmenoğlu, 2016

Ulu ve Akyol, 2016

Ulu ve Başaran, 2013

(Pause, Prompt, Praise) Metodu

Rehberli Okuma

Yankılayıcı Okuma Okuma)

Dinlenmesi Stratejisi Eğitim Programı (OKA²DEP) Haritası, Eko Okuma)

Altı Dakika Yöntemi

Rehberli Okuma

Okuma Stratejisi

Stratejisi

Zenginleştirilmiş Okuma Programı

Destekleme

Öğrenme Stilleri (i̇şitsel ve Görsel)

Tekrarlı Okuma

Yapılandırıcı Yöntem ve Teknikler

Çoklu Duyusal Yaklaşım

Okuma Destek Programı (ODEP)

Rehberli Okuma

Nörolojik Etki Yöntemi

Renkli Metinler

Akran Öğretimi

Soru- Okuma- Özetleme) Stratejisi

Video Öz Değerlendirme Tekniği
Bireyselleştirilmiş Okuma Programı

14 oturum (80

dk.)

120 ders saati

126 ders saati

12 hafta

12 hafta

11 hafta

60 ders saati

Akıcı Okuma Stratejileri (Eko Okuma, Tekrarlı

Kelime Tekrar Tekniği ve Paragrafın Önceden

Akıcı Okuma ve Okuduğunu Anlama Destek

Öğrenme Stilleri (Dokunsal Öğrenme, Kelime Kutusu, Kum Havuzu, Kelime Tekrar, Hikâye

Ana Fikir Belirleme Becerisi Öğretimi

30 gün

$(1-1,5$

saat)

16 oturum

49 ders saati

72 ders saati

15 oturum (20- 30

dk.)

32 saat

Paragrafın Önceden Dinlenmesi Stratejisi ve Eşli 13 saat

Tahmin- İnceleme- Özetleme Örgütleme- 165 saat

Değerlendirme (TiÖD) Okuduğunu Anlama

Koro Okuma, Tekrarlı Okuma ve Yardımlı Okuma

Tekrarlı Okuma ve Grafiksel Sembollerle

Tablet Bilgisayar Destekli Sağaltım Programı

Tekrarlayıcı Okuma ve Birlikte Okuma

Tekrarlı Okuma ve Yankılayıcı Okuma

Model Okuma, Tekrarlı Okuma, Hata Düzeltme ve Kendini İzleme Stratejisi Sağaltım Paketi

Yapılandırıcı Okuma ve Anlama Etkinlikleri

Çoklu Ortam Materyalleri (e-defter, eğitim CD'si)

Tekrarlayıcı Okuma ve PQRS (Göz Gezdirme-
90 ders saati

138 ders saati

4 hafta

12,13 , ve 15

oturum

128 saat

30 saat

64 ders saati

16 ders saati

16 saat

228 ders saati

48 saat

6 hafta

15 saat

96- 35 ders saati

48 saat

30 ders saati

20 saat

45 ders saati

43 saat

12 hafta (haftada

3 gün) 
Türkiye'de Okuma Güçlüğünü Gidermeye Odaklanan İlkokul Düzeyindeki Araştırmaların İncelenmesi: 2000 2020 Dönemi

Urfalıoğlu Eroğlu, 2020

Uzunkol, 2013

Yamaç, 2015

Yangın ve Sidekli, 2006

Yılmaz, 2006

Yücel, 2009

Yüksel, 2010
Nörogeribildirim ve Çoklu Duyulu Öğrenme (Auto Train Brain Cep Telefonu Uygulaması)

Kelime Tekrar, Eko Okuma, Tekrarlı Okuma, 32 saat

Paylaşarak Okuma, Eşli Okuma

Tekrarlı Okuma, Eşli Okuma ve Kelime İnşası 30 saat

Fernald Tekniği

Tekrarlı Okuma

Sesbilgisel Farkındalık Eğitimi

6 hafta

48 saat

20 oturum

dk.)

Kelime Kutusu Stratejisi ve Paragrafın Önceden 33 saat

Tablo 4'e göre araştırmaların yaklaşık \%40'ında okuma problemlerinin giderilmesinde ve okuma becerilerinin geliştirilmesinde akıcı okuma strateji, yöntem ve tekniklerinin (tekrarlı okuma, eko okuma, eşli okuma, okuyucu tiyatroları, rehberli okuma, koro okuma, model okuma, paylaşımlı okuma, birlikte okuma vb.) kullanıldığı görülmektedir. Buna ek olarak yaklaşık \%28'inde okuma güçlüğünün giderilmesinde çeşitli stratejilerin (3P, PQRS, Nörolojik Etki, Altı Dakika, Çoklu Duyusal Yaklaşım, Fernald, Bir Öğretmen Bir Yardımcı, Kelime Kutusu, Paragrafın Önceden Dinlenmesi, Video Öz Değerlendirme, TiÖD, HELPS vb.), yaklaşık \%18'inde ise bireyselleştirilmiş-zenginleştirilmiş okuma programlarının uygulandığı görülmektedir.

Uygulama süreleri incelendiğinde ise araştırmalarda müdahale uygulamalarının ders saati, oturum, saat ve hafta şeklinde farklı birimlerle ifade edildiği görülmektedir. Müdahale uygulamalarının minimum, maksimum ve ortalamalarına ilişkin bulgular Tablo 5'te gösterilmektedir.

Tablo 5.

Müdahale Uygulamalarının Süreleri (Minimum, Maksimum ve Ortalama)

\begin{tabular}{lllll}
\hline Birim & Çalışma Sayısı & Minimum & Maksimum & Ortalama \\
\hline Ders saati & 20 & 16 & 228 & 69,4 \\
Saat & 22 & 12 & 165 & 46,1 \\
Oturum & 8 & 12 & 60 & 24,9 \\
Hafta & 7 & 4 & 12 & 9 \\
\hline
\end{tabular}

Tablo 5’e göre okuma güçlüğünü gidermeye yönelik uygulamaların minimum 16 ders saati-12 saat- 12 oturum-4 hafta, maksimum 228 ders saati- 165 saat- 60 oturum-12 hafta süresince gerçekleştirildiği görülmektedir. Tüm çalışmalardaki müdahale uygulamaların ortalamaları hesaplandığında ise 69,4 ders saati- 46,1 saat- 24,9 oturum- 9 hafta olduğu görülmektedir.

\section{Müdahale Uygulamalarının Etkileri/Sonuçları}

Çalışma kapsamında incelenen 58 araştırmada okuma problemlerini gidermeye yönelik gerçekleştirilen uygulamaların sonuçları/ etkileri ile ilgili bulgular öncelikle; okuma hızı, okuma hataları ve kelime tanıma yüzdesi değişkenlerine göre değerlendirilmiştir. Bu değişkenlere ait ortalamaların hesaplanmasında müdahale öncesi ve sonrası verilerin eksiksiz olarak belirtildiği çalışmalardaki değerler dikkate alınmıştır. Müdahale öncesi veya müdahale sonrası puanlardan herhangi biri eksik olan ya da sayısal değer yerine yalnızca düzey belirten araştırma verileri ortalama hesaplamasının dışında tutulmuştur. Tablo 6 'da okuma hızı, okuma hataları ve kelime tanıma yüzdelerine ilişkin değerler sunulmuştur. Bu değerler her bir araştırmanın kendi katılımcılarının ortalamalarını ifade etmektedir. Ancak sınıf düzeylerine göre okuma hızı, okuma hatası ve kelime tanıma yüzdesi ortalamaları hesaplanırken araştırma sayısı değil her bir sınıf düzeyindeki toplam öğrenci sayısı dikkate alınmıştır. Ek olarak birden fazla sınıf düzeyinden öğrencilerle yapılan araştırmalardan okuma puanları (okuma hızı, okuma hataları, kelime tanıma yüzdesi) her sınıf düzeyi için ayrı ayrı belirtilen çalışmalar ortalamaların hesaplanmasına dâhil edilirken okuma puanı her sınıf düzeyi için ayrı ayrı belirtilmeyen 
çalışmalar (Atmaca, 2020; Şahin ve Çakır, 2018; Urfalıoğlu Eroğlu, 2020; Yücel, 2009) ortalama hesaplamalarına dâhil edilememiştir.

Incelenen araştırmalardaki okuma hızı, okuma hataları ve kelime tanıma yüzdesi ortalamalarına ilişkin bilgiler Tablo 6'da gösterilmektedir.

Tablo 6.

Araştırmalarda Okuma Hızı, Okuma Hataları ve Kelime Tanıma Yüzdesi Ortalamaları

\begin{tabular}{|c|c|c|c|c|c|c|c|}
\hline \multirow[t]{2}{*}{ Yazar(lar) } & \multirow{2}{*}{$\begin{array}{l}\text { Sınıf } \\
\text { Düzeyi }\end{array}$} & \multicolumn{2}{|l|}{ Okuma Hızı } & \multicolumn{2}{|c|}{ Okuma Hataları } & \multicolumn{2}{|c|}{ Kelime Tanıma (\%) } \\
\hline & & $\begin{array}{l}\text { Müdahale } \\
\text { Öncesi }\end{array}$ & $\begin{array}{l}\text { Müdahale } \\
\text { Sonrası }\end{array}$ & $\begin{array}{l}\text { Müdahale } \\
\text { Öncesi }\end{array}$ & $\begin{array}{l}\text { Müdahale } \\
\text { Sonrası }\end{array}$ & $\begin{array}{l}\text { Müdahale } \\
\text { Öncesi }\end{array}$ & $\begin{array}{l}\text { Müdahale } \\
\text { Sonrası }\end{array}$ \\
\hline $\begin{array}{ll}\text { Ekiz, Erdoğan } \\
\text { ve Uzuner, } \\
2011 \\
\end{array}$ & 1 & 7 & 44 & - & - & Endişe & Öğretim \\
\hline Ortalama & 1 & 7 & 44 & - & - & Endişe & Öğretim \\
\hline Akın, 2020 & 2 & 32,67 & 60,17 & 11,97 & 4,59 & - & - \\
\hline $\begin{array}{l}\text { Aktepe ve } \\
\text { Akyol, } 2015\end{array}$ & 2 & - & - & 31 & 7 & - & - \\
\hline $\begin{array}{l}\text { Akyol ve } \\
\text { Çoban Sural, } \\
2021\end{array}$ & 2 & 18,79 & 70,75 & 42 & 8 & 75 & 95 \\
\hline $\begin{array}{l}\text { Akyol ve } \\
\text { Sever, } 2019\end{array}$ & 2 & 0 & - & 92 & 41 & - & - \\
\hline $\begin{array}{ll}\text { Başar, Göncü } \\
\text { ve } & \text { Baran, } \\
2021 & \end{array}$ & 2 & - & - & - & - & - & - \\
\hline $\begin{array}{l}\text { Baştuğ ve } \\
\text { Öncü, } 2020\end{array}$ & 2 & 39,5 & 103,5 & 4 & 1,5 & 89,66 & 98,55 \\
\hline $\begin{array}{l}\text { Dağlı } \\
\text { Gökbulut, } \\
\text { Akçamete ve } \\
\text { Güneyli, } 2020\end{array}$ & 2 & - & - & - & - & - & - \\
\hline Dinç, 2017 & 2 & 2 & 50 & 6 & 0 & Endişe & Serbest \\
\hline $\begin{array}{l}\text { Dündar ve } \\
\text { Akyol, } 2014\end{array}$ & 2 & - & - & 75 & 8 & - & - \\
\hline Ege, 2019 & 2 & 45,33 & 78,33 & 17,66 & 4 & 82,33 & 95,66 \\
\hline Görgün, 2018 & 2 & 30,5 & 50 & - & - & 79 & 95,5 \\
\hline Özbek, 2014 & 2 & 23 & 35 & 4 & 1 & - & - \\
\hline Ortalama & 2 & 32,46 & 62,99 & 17,09 & 5,43 & 82,41 & 96,26 \\
\hline $\begin{array}{l}\text { Akyol ve } \\
\text { Ketenoğlu } \\
\text { Kayabaşı, } \\
2018\end{array}$ & 3 & - & - & - & - & 51 & 96 \\
\hline Balıkçı, 2020 & 3 & 40,5 & 86,5 & - & - & - & - \\
\hline $\begin{array}{l}\text { Çayır ve Balcı, } \\
2017\end{array}$ & 3 & 1 & 23 & 50 & 8 & 50 & 92 \\
\hline $\begin{array}{l}\text { Doğuyurt ve } \\
\text { Doğuyurt, } \\
2016\end{array}$ & 3 & - & - & - & - & - & - \\
\hline Ege, 2019 & 3 & 61 & 76,5 & 44 & 28 & 77,5 & 93 \\
\hline Görgün, 2018 & 3 & 20 & 102 & - & - & 73 & 98 \\
\hline
\end{tabular}


Türkiye'de Okuma Güçlüğünü Gidermeye Odaklanan İlkokul Düzeyindeki Araştırmaların İncelenmesi: 20002020 Dönemi

\begin{tabular}{|c|c|c|c|c|c|c|c|}
\hline Karasakaloğlu & 3 & - & - & - & - & 85,66 & 93,66 \\
\hline ve Saraçlı & & & & & & & \\
\hline Çelik, 2018 & & & & & & & \\
\hline Okur ve & 3 & - & - & - & - & - & - \\
\hline Öztürk, 2018 & & & & & & & \\
\hline Özbek, 2014 & 3 & 30 & 44,5 & 1 & 1 & - & - \\
\hline Özkara, 2010 & 3 & - & - & - & - & Endişe & Öğretim \\
\hline Sağlam, 2019 & 3 & - & - & - & - & $<90$ & 93,5 \\
\hline Sirem, 2020 & 3 & 56,5 & 82,5 & - & - & 87,33 & 96,16 \\
\hline Sözen, 2017 & 3 & - & - & - & - & $<90$ & 97,6 \\
\hline Şahin ve & 3 & - & - & 45 & 8 & 72 & 95 \\
\hline Baştuğ, 2020 & & & & & & & \\
\hline $\begin{array}{l}\text { Ulu ve Akyol, } \\
2016\end{array}$ & 3 & 12 & 42 & - & - & - & - \\
\hline $\begin{array}{l}\text { Uzunkol, } \\
2013\end{array}$ & 3 & 27 & 40 & - & - & $<90$ & 94 \\
\hline Yılmaz, 2006 & 3 & - & - & - & - & - & - \\
\hline Ortalama & 3 & 41,37 & 69,81 & 30,83 & 12,33 & 78,80 & 95,00 \\
\hline $\begin{array}{l}\text { Akyol ve } \\
\text { Boyacı } \\
\text { Altınay, } 2019\end{array}$ & 4 & 20 & 32 & 58 & 8 & 55 & 93 \\
\hline $\begin{array}{l}\text { Akyol ve } \\
\text { Kodan, } 2016\end{array}$ & 4 & 35 & 55 & - & - & 52,5 & 92 \\
\hline $\begin{array}{l}\text { Balcı ve Çayır, } \\
2017\end{array}$ & 4 & 0 & 22 & - & 29 & - & - \\
\hline Balıkçı, 2020 & 4 & 41 & 86,66 & - & - & - & - \\
\hline $\begin{array}{l}\text { Çeliktürk } \\
\text { Sezgin ve }\end{array}$ & 4 & 15 & 43 & 20 & 8 & 90 & 96 \\
\hline Akyol, 2015 & & & & & & & \\
\hline $\begin{array}{l}\text { Duran ve } \\
\text { Sezgin, 2012a }\end{array}$ & 4 & - & - & - & - & $<90$ & 97 \\
\hline $\begin{array}{l}\text { Duran ve } \\
\text { Sezgin, 2012b }\end{array}$ & 4 & - & - & - & - & $<90$ & 98 \\
\hline Görgün, 2018 & 4 & 37,5 & 80 & - & - & 87,5 & 95 \\
\hline Gül, 2019 & 4 & 20 & 38 & 58 & 11 & Endişe & Serbest \\
\hline Gürbüz, 2015 & 4 & - & - & - & - & - & - \\
\hline İlter, 2018 & 4 & - & - & - & - & - & - \\
\hline $\begin{array}{l}\text { Kardaş İşler } \\
\text { ve Şahin, } \\
2016\end{array}$ & 4 & - & - & 19 & 4 & - & - \\
\hline $\begin{array}{l}\text { Kaşdemir, } \\
2020\end{array}$ & 4 & - & - & - & - & 89 & 94 \\
\hline Kodan, 2015 & 4 & 30,91 & 44,58 & - & - & 68,79 & 91,54 \\
\hline $\begin{array}{l}\text { Kuruyer, } \\
2014\end{array}$ & 4 & - & - & 122,25 & 9,37 & - & - \\
\hline $\begin{array}{l}\text { Özdemir, } \\
2013\end{array}$ & 4 & 13 & 27,5 & 65 & 7,5 & Endişe & 92 \\
\hline Peksoy, 2018 & 4 & 84 & 111,5 & 25,75 & 11,5 & 86,75 & 95 \\
\hline Sert, 2019 & 4 & 38 & 74,33 & - & - & 91,03 & 97,91 \\
\hline Sidekli, 2010b & 4 & - & - & 63,62 & 16,87 & - & - \\
\hline $\begin{array}{l}\text { Taşkaya, } \\
2010\end{array}$ & 4 & - & - & 7 & 4 & - & - \\
\hline
\end{tabular}




\begin{tabular}{|c|c|c|c|c|c|c|c|}
\hline $\begin{array}{l}\text { Türkmenoğlu, } \\
2016\end{array}$ & 4 & 42 & 81,6 & - & - & 84 & 96 \\
\hline $\begin{array}{l}\text { Ulu ve } \\
\text { Başaran, } \\
2013\end{array}$ & 4 & 32 & 56,6 & 24 & 8 & Endişe & 96 \\
\hline Yamaç, 2015 & 4 & 20,8 & 34,2 & 33 & 2 & Endişe & 99 \\
\hline Ortalama & 4 & 37,88 & 65,63 & 67,38 & 9,94 & 79,76 & 94,51 \\
\hline $\begin{array}{l}\text { Akyol ve } \\
\text { Yıldız, } 2010\end{array}$ & 5 & 3 & 34 & 12 & 1 & 52 & 99 \\
\hline Dağ, 2010 & 5 & 55,35 & 74,83 & 81 & 31 & Endişe & Öğretim \\
\hline $\begin{array}{l}\text { Özdemir, } \\
2013\end{array}$ & 5 & 63 & 50,5 & 42 & 15 & Endişe & 95 \\
\hline $\begin{array}{l}\text { Sidekli ve } \\
\text { Yangın, } 2005\end{array}$ & 5 & - & - & - & - & - & - \\
\hline Sidekli, 2010a & 5 & 60 & 91 & - & - & - & - \\
\hline $\begin{array}{l}\text { Yangın ve } \\
\text { Sidekli, } 2006\end{array}$ & 5 & - & - & - & - & - & - \\
\hline Yüksel, 2010 & 5 & 40 & 61 & 23 & 8 & Endişe & 95 \\
\hline Ortalama & 5 & 54,18 & 76,83 & 40,00 & 14,00 & 52 & 99 \\
\hline
\end{tabular}

Tablo 6'ya göre müdahale uygulamaları sonrasında tüm sınıf düzeylerinde öğrencilerin okuma hızı ve kelime tanıma yüzdelerinin arttığı ve okuma hatalarının azaldığı görülmektedir. Birinci sınıf düzeyinde yalnızca bir araştırma çalışma kapsamında incelendiği için ortalama değerler bu çalışmanın değerleridir. Okuma hızı ortalamaları incelendiğinde; müdahale öncesinde okuma hızı ortalamasının ikinci sınıf düzeyinde 32,46 kelime, üçüncü sınıf düzeyinde 41,37 kelime, dördüncü sınıf düzeyinde 37,88 kelime ve beşinci sınıf düzeyinde 54,18 kelime olduğu görülmektedir. Müdahale sonrası okuma hızı ortalamalarının; ikinci sınıf düzeyinde 62,99 kelime, üçüncü sınıf düzeyinde 69,81 kelime, dördüncü sınıf düzeyinde 65,63 kelime ve beşinci sınıf düzeyinde 76,83 kelime olduğu görülmektedir. Müdahale öncesi ve sonrası okuma hızı ortalamalarındaki artışların ise ikinci sınıflarda 30,53 kelime (\%94), üçüncü sınıflarda 28,44 kelime (\%68), dördüncü sınıflarda 27,75 kelime (\%73) ve beşinci sınıflarda 22,65 kelime (\%41) olduğu görülmektedir.

Okuma hataları ortalamaları incelendiğinde müdahale öncesi ve sonrası; ikinci sınıf düzeyinde 11,66 (\%68), üçüncü sınıf düzeyinde 18,50 (\%60), dördüncü sınıf düzeyinde 57,44 (\%85) ve beşinci sınıf düzeyinde 26,00 (\%65) kelimelik bir azalma olduğu görülmektedir. Kelime tanıma yüzdeleri incelendiğinde ise ikinci sınıf düzeyinde $\% 13,85$, üçüncü sınıf düzeyinde $\% 16,20$, dördüncü sınıf düzeyinde $\% 14,75$ ve beşinci sınıf düzeyinde $\% 47$ 'lik bir artış olduğu görülmektedir. Beşinci sınıf düzeyinde yalnızca bir araştırmada kelime tanıma yüzdeleri verildiği için bu değerler beşinci sınıf ortalamasını yansıtmamaktadır.

Okuma güçlüğünü gidermeye yönelik yapılan çalışmalarda okuma hızı, okuma hataları ve kelime tanıma yüzdelerine ek olarak; prozodik okuma, okuduğunu anlama, okuma motivasyonu, okuyucu benlik algısı, okumaya verilen değer, hece birleştirme, fonolojik farkındalık, harf tanıma, kopyalama, dikte etme, harf okuma, alfabe okuma, kelime okuma, çözümleme, hece okuma, okuma tutumu, görsel okuma, sesli okuma, dinlediğini anlama, dikkat ve bellek performansı, okuma verimliliği, akıcl okuma, temel okuma ve yazma becerilerinin de incelendiği görülmektedir. Bu becerilere ait araştırma bulguları standart testler ya da ölçümlerle elde edilemediğinden sayısal olarak değerlendirmek (ortalamalar vb.) mümkün olmamaktadır. Ancak araştırmaların tamamında müdahale uygulamaları sonrasında bu becerilerin geliştiğini söylemek mümkündür.

\section{Tartışma, Sonuç ve Öneriler}

Okuma güçlüğünün giderilmesine yönelik Türkiye'de, 2000-2020 yılları arasında gerçekleştirilen bilimsel çalışmaların incelendiği bu araştırmada; çalışmaların son on yılda daha yoğun gerçekleştirildiği görülmektedir. Alanyazındaki diğer derleme çalışmalarında da benzer bir eğilimin 
Türkiye'de Okuma Güçlüğünü Gidermeye Odaklanan İlkokul Düzeyindeki Araştırmaların İncelenmesi: 20002020 Dönemi

olduğu söylenebilir. Örneğin, Pürsün ve Sarı'nın (2019) araştırmalarında, özel öğrenme güçlüğü olan öğrencilerin okuduğunu anlama becerilerine yönelik araştırmaların son yıllarda yoğunlaştığı bulunmuştur. Benzer şekilde Görgün ve Melekoğlu'nun (2019) Türkiye'de 1972-2017 yıları arasında özel öğrenme güçlüğü ile ilgili yapılan çalışmaları incelendikleri araştırmada da son on yılda araştırma sayılarında hızlı bir artış olduğu sonucuna ulaşılmıştır. Doğan ve Delialioğlu'nun (2020) öğrenme güçlüğünde teknoloji kullanımı üzerine 1995-2018 yılları arasında yayınlanan çalışmaları inceledikleri araştırmada da incelenen çalışmaların yarıdan fazlasının 2012 yılı ve sonrasında gerçekleştirildiği sonucu elde edilmiştir. Özel eğitim hizmetleri ile ilgili dünyada ve Türkiye'de yapılan hukuki, sosyal ve akademik çalışmaların 2000'li yıllardan itibaren yoğunluk kazandığı görülmektedir. Özel eğitimle ilgili kanuni düzenlemeler, özel eğitim okullarının yaygınlaşması, özel eğitime ihtiyaç duyan çocukların tanılanmasıyla ilgili süreçlerin hızlanması, özel eğitimle ilgili sivil toplum kuruluşlarının çoğalması, toplumdaki farkındalığın artması ve özellikle lisansüstü özel eğitim programlarının üniversitelerde yaygınlaşması gibi önemli gelişmelerin de son yirmi yılda önem kazandığı görülmektedir. Dolayısıyla genelde özel eğitim, özelde ise okuma güçlüğü ile ilgili yapılan bilimsel çalışmaların son yıllarda yoğunluk kazanmasının bu süreçle paralellik gösterdiği söylenebilir.

Okuma güçlüğünün giderilmesine odaklanarak yapılan çalışmaların yaklaşık \%62'sinin makale türünde \%38'inin ise yüksek lisans ya da doktora tezi türünde yayınlandığı görülmektedir. Araştırmalar yöntem bakımından incelendiğinde; \%70,7'sinin nitel, \%29,3'ünün nicel yaklaşımlarla gerçekleştirildiği sonucuna ulaşımıştır. Araştırma desenleri dikkate alındığında ise araştırmaların en fazla eylem araştırması ve durum çalışması desenlerinde gerçekleştirildiği ve bunları tek denekli deneysel araştırmaların izlediği söylenebilir. Pürsün ve Sarı'nın (2019) araştırmalarında, özel öğrenme güçlüğü olan öğrencilerin okuduğunu anlama becerilerine yönelik yapılan çalışmaların da çoğunlukla tek denekli araştırma modeliyle desenlendiği sonucu elde edilmiştir. Deveci ve Koç'un (2020) ve Görgün ve Melekoğlu'nun (2019) araştırmalarında çalışmaların çoğunun tarama modeli, betimsel desen, yarı deneysel desen, deneysel desen, ilişkisel tarama modeli ve eylem araştırması desenlerinde yürütüldüğü sonucu elde edilmiştir. Yıldız ve Melekoğlu'nun (2020) araştırmasında ise incelenen araştırmaların yaklaşık \%52'sinin deneysel desende yürütüldüğü sonucuna ulaşılmıştır. Bu sonuçlar birlikte değerlendirildiğinde öğrenme güçlüğü ile ilgili yapılan araştırmalardan müdahale uygulamalarına odaklananlarda eylem araştırması, deneysel ve yarı deneysel desendeki çalışmaların, öğrenme güçlüğü ile ilgili yapılan çalışmaların genel olarak incelendiği araştırmalarda ise tarama çalışmaları ve korelasyonel çalışmaların daha çok kullanıldığı söylenebilir. Bu araştırma da doğrudan okuma güçlüğünün giderilmesine odaklanan müdahale uygulamalarını temele alan bir araştırma olduğu için incelenen araştırmaların çoğunlukla eylem araştırması, durum çalışması ve deneysel desenlerde tasarlanmış olmaları beklenen bir sonuçtur. Veri toplama araçları açısından incelendiğinde ise araştırmalarda en çok kullanılan veri toplama aracının Yanlış Analizi Envanteri olduğu görülmektedir. Buna ek olarak; Okuma Motivasyonu Profili Ölçeği, araştırma günlükleri ve gözlemleri, Çok Boyutlu Okunaklılık Ölçeği, görüşme formu, Okuma Tutum Ölçeği, TILLS Testi, Sesbilgisel Farkındalık Becerileri Değerlendirme Aracı ve Ankara Artikülasyon Testi gibi veri toplama araçlarının da farklı değişkenlerin değerlendirilmesinde kullanıldığı görülmektedir. Ayrıca her ne kadar okuma hızı ve hatası veri toplama aracı, prozodik okuma düzey belirleme aracı, okuduğunu anlama veri toplama aracı, ses ve video kayıtları, okuma metinleri, kopyalama ve dikte metinleri, harf listesi, kelime listesi, heceleme listesi, kelime okuma bilgisi testi, program tabanlı ölçme, okuduğunu anlama becerileri izlem çizelgesi, okuduğunu anlama envanteri, okuduğunu anlama değerlendirme aracı, dinlediğini anlama ölçeği, kelime anlama düzey ve yüzdeliğini belirleme kılavuzu, prozodik okuma ölçeği, sesli okuma hatalarını belirleme ölçeği, okuma- yazma beceri rubriği gibi farklı kavramlarla tanımlansalar da bu araçların çoğunun; okuma hızı, kelime tanıma yüzdesi, okuduğunu anlama ve akıcı okuma gibi okuma becerilerini performans temelli ölçme uygulamalarını içerdiği söylenebilir. Okuma becerilerinin ölçülmesinde; okuma becerisi değerlendirme ölçeği, kontrol listeleri, öz değerlendirme formları, gözlem formları, okuma gelişim dosyaları, okuma listeleri, elektronik dil portfolyoları gibi araçlar kullanılabilmektedir (Duran ve Öztürk, 2019). Okuma güçlüğünü gidermeye dönük yapılan çalışmalarda ise çoğunlukla akıcı okuma ve okuduğunu anlama becerilerine yoğunlaşıldığı görülmektedir. Dolayısıyla araştırmalarda Yanlış Analizi Envanteri, okuma metinleri, anlama testleri ve performans temelli ölçme 
uygulamalarının kullanılmasının beklenen bir durum olduğu söylenebilir. Çünkü Yanlış Analizi Envanteri akıcı okuma becerilerini ölçmeye yönelik seslendirme ve ortam ölçeği, okuduğunu anlamaya yönelik soru ölçeği alt boyutlarından oluşmaktadır. Ve okuduğunu anlama becerisinin ölçülmesinde genellikle metin temelli anlama soruları kullanılmaktadır. Dolayısıyla bu envanterin araştırmalarda en çok kullanılan veri toplama aracı olmasının kullanışılık özellikleri ile ilgili olduğu söylenebilir.

Sınıf düzeyi açısından bakıldığında araştırmaların en fazla dördüncü sınıf öğrencileri ile gerçekleştirildiği bu araştırmadan elde edilen bir diğer sonuçtur. Bunu sırasıyla üçüncü, ikinci ve beşinci sınıf öğrencileri ile yapılan çalışmalar takip etmektedir. Birinci sınıf öğrencilerinin okuma yazmayı öğrenme süreçleri henüz devam ettiğinden, okuma güçlüklerinin giderilmesine yönelik az sayıda çalışma yapılmasının beklenilen bir durum olduğu söylenebilir. Pürsün ve Sarı́nın (2019) araştırmasında çalışmaların çoğunlukla üçüncü, dördüncü, altıncı ve sekizinci sınıf öğrencileri ile yürütüldüğü sonucuna ulaşıımıştır. Yıldız ve Melekoğlu'nun (2020) araştırmalarında ise çalışmaların çoğunlukla ortaokul düzeyinde gerçekleştirildiği ve bunu ilkokul düzeyindeki çalışmaların izlediği, ayrıca ilkokul düzeyindeki çalışmaların ikinci, üçüncü ve dördüncü sınıf öğrencileriyle gerçekleştirildiği ve birinci sınıf öğrencileri ile yapılan herhangi bir çalışmaya ulaşılmadığı sonucuna ulaşılmıştır. Görgün ve Melekoğlu'nun (2019) araştırmaları da özel öğrenme güçlüğü alanındaki çalışmaların çoğunlukla ilkokul öğrencileri ile gerçekleştirildiğini göstermektedir. Buradan hareketle okuma güçlüğü çalışmalarında genellikle ilkokulun son sınıflarındaki öğrencilerle çalışıldığı çıkarımı yapılabilir. Balıkçı'ya (2020) göre özel öğrenme güçlüğü genellikle ilkokul döneminde tanılanmaktadır. Ayrıca okuma güçlüğünün fark edilmesinin genellikle ilkokul döneminde mümkün olabildiği (Hultquist, 2006) düşünüldüğünde; birinci sınıfta okuma güçlüğü belirtileri gösteren bireyin tanılanma sürecinin ikinci sınıfta tamamlandığı çıkarımı yapılabilir. Morrison'a (2016) göre de özel öğrenme güçlüğü ilkokul ikinci sınıfta kendine belli etmektedir. Dolayısıyla birinci sınıf çocuklarıyla gerçekleştirilen okuma güçlüğü çalışmaları, okuma güçlüğünü gidermeye dönük olmaktan çok okuma güçlüğü riski taşıyan bireylere okuma yazma öğretimi uygulamalarını içermektedir.

Bu araştırma kapsamında incelenen 58 araştırmanın 30'unun tek katılımcıyla yürütüldüğü ve yaklaşık \%90'ının sekiz veya daha az katılımcı ile gerçekleştirildiği sonucu elde edilmiştir. Bu araştırmanın okuma güçlüğünün giderilmesine yönelik 'müdahale uygulamaları' çalışmalarına odaklandığı düşünüldüğünde araştırmaların genellikle az sayıda katılımcıyla gerçekleştirilmiş olmasının beklenen bir sonuç olduğu söylenebilir. Ayrıca okuma güçlüğü yaşayan öğrencilerin okuma becerilerinin mevcut düzeyi, öğrenme ihtiyaçları ve bireysel özellikleri kişiye özel bir nitelik taşıdığı için okuma güçlüğünün giderilmesinde bireyselleştirilmiş uygulamaların kullanılması bu durumu açıklar niteliktedir. Ayrıca çok katılımcılı çalışmalarda da birden fazla katııımcı olmasına rağmen müdahale uygulamalarının toplu öğretim etkinliklerinden daha çok bireysel uygulamalara odaklanması da bu çıkarımı desteklemektedir. Çalışmalar katılımcıların cinsiyetleri açısından incelendiğinde ise erkeklerle yürütülen çalışmaların fazla olduğu sonucuna ulaşılmıştır. Yıldız ve Melekoğlu'nun (2020) çalışmalarında da erkek öğrencilerle yapılan öğrenme güçlüğü çalışmalarının kızlarla yapılanlara oranla daha fazla olduğu görülmektedir. Öğrenme güçlüğünün erkek öğrencilerde görülme olasılığının kızlara göre daha fazla olduğu (Liederman, Kantrowitz ve Flannery, 2005; Rutter vd., 2004) dikkate alındığında bu durumun beklenen bir sonuç olduğunu söylemek mümkündür.

Çalışma kapsamında incelenen araştırmalarda okuma problemlerinin genellikle okuma güçlüğü kavramıyla ifade edildiği sonucuna ulaşılmıştır. Bunu sırasıyla öğrenme güçlüğü, okuma problemi, okuma bozukluğu ve disleksi kavramlarının izlediği sonucu elde edilmiştir. Araştırma sonuçları, incelenen çalışmaların büyük bir çoğunluğunda okuma güçlüğünün araştırmacılar tarafından yapılan birtakım testler ya da okuma becerileri ölçümleriyle belirlendiğini göstermektedir. Ayrıca bazı araştırmalarda okuma güçlüğünün belirlenmesinde RAM ve hastane raporlarının bazılarında ise RAM raporları ve araştırmacılar tarafından yapılan testlerin birlikte kullanıldığı görülmektedir. Özel eğitim alanında çalışan araştırmacıların gerçekleştirdiği çalışmalarda okuma güçlüğünün belirlenmesinde genellikle RAM ve hastane raporlarının ve çeşitli zekâ testlerinin sıklıkla kullanılması, sınıf öğretmenliği ve Türkçe öğretimi alanında çalışan araştırmacıların gerçekleştirdiği araştırmalarda ise araştırmacılar tarafından okuma becerilerinin değerlendirilmesini içeren uygulamaların sıklıkla kullanılması bu araştırmanın dikkat çeken bir diğer sonucudur. Bu durum; özel eğitim alanındaki araştırmacıların 
Türkiye'de Okuma Güçlüğünü Gidermeye Odaklanan İlkokul Düzeyindeki Araştırmaların İncelenmesi: 20002020 Dönemi

okuma güçlüğüne özel öğrenme güçlüğünün bir türü olarak daha çok zihinsel boyutuyla yoğunlaşmasıyla, sınıf öğretmenliği ve Türkçe öğretimi alanındaki araştırmacıların ise okuma güçlüğünü okuma becerilerinin geliştirilmesi boyutuyla ele almalarıyla açıklanabilir. İncelenen araştırmalarda okuma güçlüğünün belirlenmesinde kullanılan testlerden bazıları; Evrensel Okuma Taraması, WISC-R Zekâ Testi, psikolojik testler, Sesli Okuma Becerisi ve Okuduğunu Anlama Testi- II, Türkçe Okul Çağı Dil Gelişim Testi, Anadolu Sak Zekâ Ölçeği, Öğrenme Güçlüğü Belirti Tarama Listesi, Okuma Güçlüğü Tanılama Envanteri, TILLS Testidir. Bununla birlikte okuma güçlüğünün belirlenmesinde en sık Yanlış Analizi Envanterinin kullanıldığı sonucuna ulaşıımıştır. Araştırmalarda kullanılan bu testlerden bazılarının kullanımı birtakım yeterlikleri ve uzmanlığı gerektirmektedir ve testi geliştirenler ya da yetki sahibi olan temsilciler tarafından verilen eğitimlere katılıp, yeterlik koşullarının gerçekleştirilmesi bu testlerin kullanılabilmesi için ön koşul gerekliliklerdir. Ekwall ve Shanker (1988) tarafından geliştirilen ve Akyol (2005) tarafından Türkçe 'ye uyarlanan Yanlış Analizi Envanteri ise öğrencilerin kelime tanıma, okuma hızı ve okuduğunu anlama becerilerini belirlemede kullanılan metin temelli standartlaştırılmamış bir ölçme ve değerlendirme aracıdır. Dolayısıyla Yanlış Analizi Envanterinin kullanılmasının diğer testlere kıyasla daha pratik ve ulaşılabilir olmasının bu sonucu ortaya çıkardığı söylenebilir. Ayrıca çalışmaların okuma güçlüğünün giderilmesine odaklandığı göz önüne alındığında Yanlış Analizi Envanteri ve okuma becerileri ölçümlerinin müdahale öncesi ve sonrası becerilerin kıyaslanmasında etkili olarak kullanılabilmesinin bu durumun nedeni olduğu söylenebilir.

$\mathrm{Bu}$ araştırma kapsamında incelenen çalışmaların katılımcılarının bilişsel, sosyal ve duygusal özellikleri incelendiğinde; ailelerin eğitim seviyesinin düşük olması, annelerin genellikle ev hanımı, babaların ise genellikle düşük ekonomik gelir getiren meslekleri yapması, ailelerin çok çocuklu olması, derse yönelik ilgisizlik, düşük akademik başarı, dikkat ve odaklanma problemleri, özgüven eksikliği, hiperaktiflik gibi özelliklere sahip oldukları sonucu elde edilmiştir. Bu özelliklerin çoğunlukla birbirini etkileyen faktörler olduğu söylenebilir. Bu özelliklerin Yurdakal'ın (2017) okuma güçlüğü yaşayan bireylerde gözlenebilen temel belirtileri betimlediği özelliklerle örtüştüğü görülmektedir. Kuruyer ve Özdemir (2019) de okuma güçlüğü yaşayan öğrencilerin okuma, yazma ve matematik gibi temel becerilerde ve dikkat, algı, bilgi işleme, bellek, motivasyon, öğrenmeye katılım gibi süreçlerde akranlarından farklılaştığını ifade etmektedir. Buna ek olarak dikkat dağıııklığı (Woolfolk Hoy, 2015) ve sosyal alanlardaki yetersizlikler (Bek ve Şen, 2014) öğrenme güçlüğü yaşayan bireylerin belirgin özellikleridir. Dolayısıyla okuma güçlüğü yaşayan öğrencilerin bilişsel, sosyal ve duygusal özelliklerinin bilinmesinin gerek okuma güçlüğünün belirlenmesinde gerekse öğrenme güçlüğü yaşayan bireylerle ilgili yapılacak sağaltım çalışmalarında önem arz ettiği söylenebilir.

Bu araştırmada okuma güçlüğünün giderilmesinde; araştırmaların çoğunda akıcı okuma strateji, yöntem ve tekniklerinin (tekrarlı okuma, eko okuma, eşli okuma, birlikte okuma, koro okuma, rehberli okuma, okuma tiyatroları vb.) kullanıldığı görülmektedir. Ayrıca bazı araştırmalarda çeşitli stratejilerin (3P, PQRS, Altı Dakika, Kelime Kutusu, Video Öz Değerlendirme, Nörolojik Etki vb.), bazılarında bireyselleştirilmiş okuma destek programlarının bazılarında ise çoklu duyusal yaklaşıma ait uygulamaların okuma güçlüğünün giderilmesinde kullanıldığı sonucuna ulaşılmıştır. Akıcı okuma bir metni; noktalama, vurgu ve tonlamaya dikkat ederek, mümkün olduğu kadar az okuma hatasıyla, zorlanmadan, konuşurmuş gibi ve anlayarak okuma olarak tanımlanmaktadır (Akyol, 2012, Rasinski, 2010; Samuels, 2006; Vilger, 2008). Okuma güçlüğü yaşayan bireylerin akıcı okumada zorluk yaşadıkları göz önüne alındığında, araştırmalarda en çok tercih edilen müdahale uygulamalarının akıcı okuma stratejileri olması beklenen bir sonuç olarak ortaya çıkmaktadır. Çünkü okuma sürecinin başarıya ulaşmasında metnin akıcı bir şekilde okunması gerekmektedir ve okuma akıcılığı okuduğunu anlamanın bir ön koşuludur (Seçkin Yılmaz ve Baydık, 2017). Ayrıca okuma güçlüğünün kişiye özgü olması ve okuma ve anlama stratejilerinin okuduğunu anlama başta olmak üzere okuma becerilerinin geliştirilmesinde etkili olması, bu uygulamaların okuma güçlüğünü gidermede sıklıkla kullanılmasını açıklar niteliktedir. Bu araştırmadan elde edilen sonuçlar, incelenen araştırmaların yalnızca dördünün yazma becerisi ile ilgili uygulamaları içerdiğini göstermektedir. Okuma ve yazmanın birbirinden bağımsız süreçler olmadığı (Koons, 2008; Parodi, 2007; Uğur, 2018) göz önüne alındığında bu sonucun dikkat çekici olduğu söylenebilir. Bu araştırmanın başka bir sonucu da okuma güçlüğünün giderilmesinde teknoloji temelli müdahale uygulamalarının incelenen araştırmaların yalnızca dördünde 
kullanılmış olmasıdır. Teknoloji, günümüzde eğitim etkinliklerinin önemli bir parçası durumundadır ve sınıflardaki varlığını günden güne artırmaktadır (Carstens, Mallon, Bataineh ve Al-Bataineh, 2021). Ek olarak, teknoloji kullanımının öğrencilerin öğrenme süreçlerine katkı sağlayabileceği araştırmalarla (Chang, Chen ve Huang, 2011; Drigas ve loannidou, 2013; King-Sears ve Evmenova, 2007) ortaya koyulmuştur. Ayrıca yurtdışında yapılan bazı çalışmalarda okuma güçlüğünün giderilmesinde; bilgisayarlı biçim temelli öğretim (Bar-Kochva, Korinth ve Hasselhorn, 2020), bilgisayar destekli çalışan bellek programı (Akbari, Soltani Kouhbanani ve Khosrorad, 2019), metinden konuşmaya teknolojisi (Grunêr, Ötsberg ve Hedenius, 2018), bilgisayar destekli sağaltıcı okuma müdahalesi (Saine vd., 2011), bilgisayar tabanlı zamansal dinleme eğitimi (O'Connor, Shapiro ve Stoddard, 1998) gibi birçok uygulamadan faydalanıldığı görülmektedir. Dolayısıyla okuma güçlüğünün giderilmesinde teknoloji temelli uygulamaların Türk öğrencilerde de etkili olabileceği düşünülmektedir. Uygulama süreleri dikkate alındığında ise araştırma sonuçları; okuma güçlüğünü gidermeye yönelik uygulamaların minimum 16, maksimum 228 ders saati süresince gerçekleştirildiğini göstermektedir. Tüm çalışmalardaki müdahale uygulamaların ortalamaları hesaplandığında ise 69,4 ders saati olduğu sonucuna ulaşılmıştır. Uygulama sürelerinin değişkenlik göstermesinin, okuma güçlüğünü gidermeye dönük uygulamaların öğrencilerin bireysel özellikleri ve ihtiyaçlarına göre planlanmasından kaynaklandığı söylenebilir.

Bu araştırmadan elde edilen son sonuç ise incelenen araştırmalarda gerçekleştirilen müdahale uygulamalarının sonuçları/etkilerine yöneliktir. Müdahale uygulamalarının; okuma hızı, kelime tanıma, prozodik okuma, okuduğunu anlama, okuma motivasyonu, okuyucu benlik algısı, okumaya verilen değer, hece birleştirme, fonolojik farkındalık, harf tanıma, kopyalama, dikte etme, harf okuma, alfabe okuma, kelime okuma, çözümleme, hece okuma, okuma tutumu, görsel okuma, sesli okuma, dinlediğini anlama, dikkat ve bellek performansı, okuma verimliliği, akıcı okuma, temel okuma ve yazma becerilerini artırdığı ve okuma hatalarını azalttığı (ikinci sınıfta \%68, üçüncü sınıfta \%60, dördüncü sınıfta \%85, beşinci sınıfta \%65) sonucuna ulaşılmıştır. Ayrıca araştırma sonuçları, müdahale öncesi okuma hızı ortalamalarının ikinci sınıfta 32,46, üçüncü sınıfta 41,37, dördüncü sınıfta 37,88 ve beşinci sınıfta 54,18 kelime olduğunu göstermektedir. Normal gelişim gösteren Türk öğrencilerin okuma hızlarıyla ilgili alanyazındaki araştırmalar incelendiğinde; birinci sınıf düzeyinde okuma hızı ortalamaları Kaya ve Doğan'ın (2016) çalışmalarında 48,96, Çayır'ın (2017) araştırmasında 42,54 kelime olarak bulunmuştur. Baştuğ'un (2012) araştırmasında okuma hızı ortalamaları; ikinci sınıfta 60,31, üçüncü sınıfta 63,16, dördüncü sınıfta 78,94 ve beşinci sınıfta 97,07 kelime olarak hesaplanmıştır. Ayrınca dördüncü sınıflarda okuma hızı ortalamalarının; Yıldız ve Çetinkaya'nın (2017) araştırmalarında 99,68 ve Büyükalan Filiz ve Boz'un (2019) araştırmalarında 92,8 kelime; beşinci sınıflarda ise Baştuğ ve Keskin'in (2012) araştırmalarında 97,07 kelime olduğu görülmektedir. Normal gelişim gösteren öğrenciler ve okuma güçlüğü olan öğrencilerin okuma hızları arasındaki bu farkların, okuma güçlüğü olan öğrencilerin normal gelişim gösteren öğrencilerden okuma hızı bakımından nasıl ayırt edilebileceği konusunda fikir verebileceği söylenebilir. Buna ek olarak çalışmalarda müdahale uygulamaları sonrası okuma hızı ortalaması ikinci sınıfta 62,99, üçüncü sınıfta 69,81, dördüncü sınıfta 65,63, beşinci sınıf düzeyinde ise 76,83 kelime olarak hesaplanmıştır. Bu sonuçlar, incelenen araştırmalarda gerçekleştirilen müdahale uygulamalarının, öğrencilerin okuma hızlarını artırmıs olduğunu göstermektedir. Benzer sonucun kelime tanıma yüzdelerinde de ortaya çıktığı söylenebilir. İncelenen çalışmalarda kelime tanıma yüzdesi ortalamaları müdahale sonrası ikinci sınıfta \%96,26, üçüncü sınıfta $\% 95,00$ ve dördüncü sınıfta \%94,51 olarak hesaplanmıştır. Kelime tanıma yüzdesinin \%99+ olması serbest okuma düzeyi, \%95+ olması öğretim düzeyi, \%90- olması ise endişe düzeyini ifade etmektedir (Akyol, 2019). Dolayısıyla incelenen araştırmalarda kullanılan müdahale uygulamalarının, öğrencilerin kelime tanıma becerisini geliştirmiş olmasına karşın (ikinci sınıfta \%13,85, üçüncü sınıfta \%17,66, dördüncü sınıfta, 12,55) serbest düzeye çıkarmada yeterli olmadı̆̆ı ifade edilebilir.

Okuma güçlüğünü gidermeye dönük Türkiye'de gerçekleştirilen müdahale uygulamalarını içeren çalışmaların incelendiği bu araştırmada, araştırma sonuçlarına dayanarak; okuma güçlüğü yaşayan öğrencilerin okuma becerilerinin yanı sıra yazma, konuşma ve dinleme becerileri ile ilgili araştırmaların yapılması önerilebilir. Türkiye'de ilkokul düzeyinde okuma güçlüklerinin giderilmesine yönelik müdahale programlarının teknoloji kullanımı bakımından çok eksik olduğu söylenebilir. 
Türkiye'de Okuma Güçlüğünü Gidermeye Odaklanan İlkokul Düzeyindeki Araştırmaların İncelenmesi: 20002020 Dönemi

Günümüzde gelinen nokta düşünüldüğünde internet tabanlı araçların, dijital ortam ve uygulamaların kullanıldığı teknoloji destekli müdahale programlarının tasarlanması, uygulanması ve etkililiğinin test edilmesine dönük araştırmalara ihtiyaç olduğu görülmektedir. Ayrıca okuma güçlüğünün giderilmesinde uygulanabilecek müdahale uygulamalarına dönük standart program tasarımları çalışılabilir ve öğrencilerin okuma becerilerinin değerlendirilmesinde kullanılabilecek standartlaştırımış (metin, soru, kelime vb. bakımından) ölçme araçları geliştirilebilir. Araştırmaların ağırlıklı olarak bilişsel becerileri geliştirmeye odaklandığı görülmektedir. Okuma güçlüğü olan öğrencilerin sosyal ve duygusal becerilerinin geliştirilmesine dönük araştırmalara ihtiyaç olduğu söylenebilir. Ayrıca okuma güçlüğü olan öğrencilerin ailelerini kapsayan ebeveyn eğitimine yönelik araştırmalar da tasarlanmalıdır. Bu araştırmalarda okuma güçlüğü olan çocuklara verilmesi gereken eğitsel, sosyal ve duygusal destek stratejilerine odaklanılabilir. Türkiye'de sınıf düzeyine göre belirlenmiş standart okuma hızı normları olmadığından akranlarından oldukça geride olan ve okuma güçlüğü yaşayan öğrenciler gözden kaçmaktadır. Araştırmada öğrenme güçlüğü olan öğrencilerin okuma performansına ilişkin ortaya çıkarılan veriler öğretmenler için yol gösterici olabilir. Örneğin okuma güçlüğü olan öğrencilerin sınıf düzeylerine göre tespit edilen okuma hızı değerleri okuma güçlüğü olan öğrencilerin belirlenmesinde öğretmenlere kolaylık sağlayabilir. Böylece okuma güçlüğü olan öğrencilerin erkenden tespit edilmesi mümkün olabilir. Ayrıca araştırmada okuma güçlüğünü gidermede etkili olduğu belirlenen müdahale programlarının öğretmenlere tanıtılmasına yönelik çalışmalar yapılabilir. Öğretmenler, etkililiği kanıtlanmış bu uygulamaları kullanarak okuma güçlüğü olan öğrencilere destek olabilir. Öğretmenler eğitim sürecinde okuma güçlüğü olan çocukların sosyal duygusal özelliklerini de dikkate almalıdır. Okuma güçlüğüne eşlik eden sosyal ve duygusal problemler, bu çocukların öğrenme kalitesini etkileyen temel unsurlardır. Bu bakımdan öğretmenler tarafından okuma güçlüğünü gidermeye dönük okul içi çalışmalarda çocukların bu özelliklerini dikkate alan bir destek süreci tasarlanabilir. Türkiye'de okuma güçlügünü gidermeye dönük araştırmalar Millî Eğitim Bakanlığı tarafından okuma güçlüğü olan öğrencilerin tespitinde ve desteklenmesinde kullanılabilecek pek çok önemli bulgu sunmaktadır. Bunlardan en önemlisi araştırmalarda etkililiği kanıtlanmış müdahale programlarıdır. Bakanlık bu müdahale programlarını modüler programlara çevirerek öğretmen eğitimleri aracılığıyla uygulamaya koyabilir. Bakanlık okulları ve öğretmenleri okuma güçlüğü olan öğrencileri desteklemek için bu programları kullanmaya ve sonuçlarını paylaşmaya teşvik edebilir.

\section{Araştırma ve Yayın Etiği}

Bu çalışmada "Yükseköğretim Kurumları Bilimsel Araştırma ve Yayın Etiği Yönergesi" kapsamında uyulması belirtilen tüm kurallara uyulmuştur. Yönergenin ikinci bölümü olan "Bilimsel Araştırma ve Yayın Etiğine Aykırı Eylemler" başlığı altında belirtilen eylemlerden hiçbiri gerçekleştirilmemiştir.

\section{Etik Kurul Izni}

Kurul adı = Ondokuz Mayıs Üniversitesi Sosyal ve Beşerî Bilimler Etik Kurulu

Karar tarihi $=26.03 .2021$

Belge sayı numarası $=2021 / 265$

\section{Yazarların Katkı Oranı}

Araştırmanın yazarları çalışmaya eşit oranda katkı sağlamıştır.

\section{Çıkar Çatışması}

Araştırmanın planlanmasından yayınlanmasına kadarki süreçlerin tamamında araştırmacılar arasında çıkar çatışmasına neden olabilecek herhangi bir durum bulunmamaktadır. 


\section{Kaynaklar}

Adams, G. ve Brown, S. (2009). The six-minute solution: A reading fluency program. Longmont, CO: Sopris West Educational Services.

Akbari, E., Soltani-Kouhbanani, S. ve Khosrorad, R. (2019). The effectiveness of working memory computer assisted program on executive functions and reading progress of students with reading disability disorder. Electronic Journal of General Medicine, 16(2), 1-7. DOI: 10.29333/ejgm/94044.

Akçay, D. (2014). ilkokul 1-4. sınıf öğretmenlerinin disleksi ile ilgili farkındalık düzeylerinin incelenmesi (Yayımlanmamış yüksek lisans tezi). Marmara Üniversitesi Eğitim Bilimleri Enstitüsü, İstanbul.

*Akın, U. (2020). Öğrenme güçlüğü riski olan öğrencilerin akıcı okuma ve okuduğunu anlama becerilerinde zenginleştirilmiş okuma becerileri müdahale paketinin etkililiği: Müdahaleye Tepki Modeli Düzey-II yaklaşımı uygulaması (Yayımlanmamış Doktora Tezi). Gazi Üniversitesi Eğitim Bilimleri Enstitüsü, Ankara.

*Aktepe, V. ve Akyol, H. (2015). Okuma güçlüğünün giderilmesi: Tek örneklemli bir durum çalışması. International Journal of Eurasia Social Sciences, 6(19), 111-126. Erişim adresi: http://www.ijoess.com/DergiTamDetay.aspx?ID=347\&Detay=Ozet

*Akyol, H. ve Çoban Sural, Ü. (2021). Okuma, okuduğunu anlama ve okuma motivasyonunun geliştirmesi: Bir eylem araştırması. Eğitim ve Bilim, 46(205), 69-92. DOI: 10.15390/EB.2020.8977.

Akyol, H. (2005). Türkçe ilkokuma yazma öğretimi. Ankara: Gündüz.

Akyol, H. (2012). Türkçe öğretimi. Ankara: Pegem Akademi.

Akyol, H. (2018). Türkçe ilk okuma yazma öğretimi. Ankara: Pegem Akademi.

Akyol, H. (2019). Türkçe öğretim yöntemleri. Ankara: Pegem Akademi.

${ }^{*}$ Akyol, H. ve Ketenoğlu Kayabaşı, Z. E. (2018). Okuma güçlüğü yaşayan bir öğrencinin okuma becerilerinin geliştirilmesi: Bir eylem araştırması. Eğitim ve Bilim, 43(193), 143-158. DOI: 10.15390/EB.2018.7240.

*Akyol, H. ve Kodan, H. (2016). Okuma güçlüğünün giderilmesine yönelik bir uygulama: Akıcı okuma stratejilerinin kullanımı. Ondokuz Mayıs Üniversitesi Eğitim Fakültesi Dergisi, 35(2), 7-21. DOI: 10.7822/omuefd.35.2.1.

*Akyol, H. ve Sever, E. (2019). Okuma yazma güçlüğü ve bir eylem araştırması: İkinci sınıf örneği. Hacettepe Üniversitesi Eğitim Fakültesi Dergisi, 34(3), 685-707. DOI: 10.16986/HUJE.2018040667.

*Akyol, H. ve Yıldız, M. (2010). Okuma bozukluğu olan bir öğrencinin okuma ve yazma becerisinin geliştirilmesine yönelik bir durum çalışması. E-Journal of New World Sciences Academy, 5(4), 1690-1700. Erişim adresi: https://dergipark.org.tr/tr/download/article-file/185729

Akyol, H., Temur, M. ve Erol, M. (2019). Görme, işitme sağlığı ve ilk okuma ve yazma. H. Akyol ve A. Şahin (Ed.), Türkçe öğretimi içinde (ss. 413-432). Ankara: Pegem Akademi.

Akyol, H., Yıldırım, K., Ateş, A., Çetinkaya, Ç. ve Rasinski, T. V. (2014). Okumayı değerlendirme. Ankara: Pegem Akademi.

Alatlı, R. (2020). Iyi ve zayıf okuyucuların okuduğunu anlama becerilerinin okumanın bileşenleri boyutunda incelenmesi (Yayımlanmamıs doktora tezi). Ankara Üniversitesi Eğitim Bilimleri Enstitüsü, Ankara.

American Psychiatric Assosication (2013). Diagnostic and statistical manual of mental disorders (DSM5) (5th ed.). Arlington, VA: American Psyhiatric.

Armbruster, B. B. (2010). Put reading first: The research building blocks for teaching children to read: Kindergarten through grade 3. Jessup: Diane.

Armbruster, B. B., Lehr, F. ve Osborn, J. (2010). Put reading first: The research building blocks for teaching children to read (Third edition). Developed by the Center for the Improvement of Early Reading Achievement (CIERA). Washington, DC: The National Institute for Literacy (NIFL).

*Atmaca, F. (2020). Bilişsel gelişim programının (COGENT) özel öğrenme güçlüğü olan öğrencilerin okuma ve yazma becerilerine etkisi (Yayımlanmamış yüksek lisans tezi). Dokuz Eylül Üniversitesi Eğitim Bilimleri Enstitüsü, İzmir. 
Türkiye'de Okuma Güçlüğünü Gidermeye Odaklanan Iilkokul Düzeyindeki Araştırmaların İncelenmesi: 20002020 Dönemi

*Balcı, E. ve Çayır, A. (2017). Çoklu Duyusal Öğrenme'nin disleksi riski olan bir ilkokul 4. sınıf öğrencisinin fonolojik farkındalık becerisine etkisi. Ana Dili Eğitimi Dergisi, 5(2), 201-216. Erişim adresi: https://app.trdizin.gov.tr/makale/TWpNNE56a3dNQT09/coklu-duyusal-ogrenme-nindisleksi-riski-olan-bir-ilkokul-4-sinif-ogrencisinin-fonolojik-farkindalik-becerisine-etkisi

*Balıkçı, Ö. S. (2020). Okumayı geliştirme programının (OGEP) özel öğrenme güçlügü olan ilkokul öğrencilerinin okuma becerileri ve motivasyonları üzerindeki etkililiği (Yayımlanmamış doktora tezi). Eskişehir Osmangazi Üniversitesi Eğitim Bilimleri Enstitüsü, Eskişehir.

Bar-Kochva, I., Korinth, S. ve Hasselhorn, M. (2020). Effects of a morpheme-based training procedure on the literacy skills of readers with a reading disability. Applied Psycholinguistics, 41(5), 10611082. DOI:10.1017/S0142716420000120.

*Başar, M., Göncü, A. ve Baran, M. S. (2021). Öğrenme güçlüğü yaşayan öğrencilerin eğitiminde bir eylem araştırması. Pamukkale Üniversitesi Eğitim Fakültesi Dergisi, 51, 327-348. DOI: 10.9779/pauefd.687030.

Baştuğ, M. (2012). ilköğretim I. kademe öğrencilerinin akıcı okuma becerilerinin çeşitli değişkenler açısından incelenmesi (Yayımlanmamış doktora tezi). Gazi Üniversitesi Eğitim Bilimleri Enstitüsü, Ankara.

Baştuğ, M. ve Keskin, H. K. (2012). Akıcı okuma becerileri ile anlama düzeyleri (basit ve çıkarımsal) arasındaki ilişki. Ahi Evran Üniversitesi Kırşehir Eğitim Fakültesi Dergisi, 13(3), 227-244. Erişim adresi: https://dergipark.org.tr/tr/pub/kefad/issue/59486/854943

*Baştuğ, M. ve Öncü, B. (2020). İkinci sınıf öğrencilerinin akıcı okuma becerilerini geliştirmede Pratik Stratejilerle Erken Okuryazarlığa Yardım Programı'nın (HELPS) kullanılması üzerine bir durum çalışması. Eğitimde Nitel Araştırmalar Dergisi, 8(4), 1147-1164. DOI: 10.14689/issn.21482624.8c.4s.4m

Baydık, B., Ergül, C. ve Bahap Kudret, Z. (2012). Okuma güçlüğü olan öğrencilerin okuma akıcılığı sorunları ve öğretmenlerinin bu sorunlara yönelik öğretim uygulamaları. Illköğretim Online, 11(3), 778-789. Erişim adresi: https://dergipark.org.tr/tr/pub/ilkonline/issue/8588/106727

Begeny, J. C. (2009). Helping early literacy with practice strategies (HELPS): A one-on-one program designed to improve students' reading fluency. Raleigh, NC: Tje HELPS Education Fund.

Bek, H. ve Şen, B. (2014). Öğrenme güçlüğü yaşayan çocukların gelişim özellikleri. S. Yıldırım Doğru (Ed.), Öğrenme güçlükleri içinde (ss. 67-78). Ankara: Eğiten Kitap.

Bender, W. N. ve Larkin, M. J. (2003). Reading strategies for elementary students with learning difficulties. California: Corwin Press, Inc.

Bender, W. N. (2012). Differentiating instruction for students with learning disabilities: New best practices for general and special educators. Thousand Oaks: Corwin.

Bıyık, M. ve Erdoğan, T. (2017). Okumayı etkileyen etmenler ve hazırık çalışmaları. F. Susar Kırmızı ve E. Ünal (Ed.), Ilk okuma yazma öğretimi içinde (ss. 111-147). Ankara: Anı.

Burns, E. (2006). Pause, prompt, praise-peer tutored reading for pupils with learning difficulties. British Journal of Special Education, 33(2), 62-67. DOI: 10.1111/j.1467-8578.2006.00416.x.

Burns, N. ve Grove, S. K. (2018). Understanding nursing research: Building an evidence-based practice. China: Saunders.

Bursuck, B. ve Blanks, B. (2010). Evidence-based early reading practices within a response to intervention system. Psychology in the Schools, 47(5), 421-431. DOI: 10.1002/pits.20480.

Büyükalan Filiz, S. ve Boz, İ. (2019). illkokul 4. sınıf öğrencilerinin akıcı okuma düzeyleri ile rutin olmayan problem çözme başarısı arasındaki ilişkinin incelenmesi. International Journal of Field Education, 5(1), 57-70. DOI: 10.32570/iojfe.524102.

Carstens, K. J., Mallon, J. M., Bataineh, M. ve Al-Bataineh, A. (2021). Effects of technology on student learning. The Turkish Online Journal of Educational Technology, 20(1), 105-113. Retrieved from: http://www.tojet.net/articles/v20i1/20113.pdf

Chang, Y. J., Chen, S. F. ve Huang, J. D. (2011). A Kinect-based system for physical rehabilitation: A pilot study for young adults with motor disabilities. Research in Developmental Disabilities, 32(6), 2566-2570. DOI: 10.1016/j.ridd.2011.07.002. 
Coltheart, M. (2005). Comprehension instruction: Research-based best practices. M. J. Snowling ve C. Hulme (Ed.), The science of reading: $A$ handbook. USA: Blackwell.

Çayır, A. (2017). Analyzing the reading skills and visual perception levels of first grade students. Universal Journal of Educational Research, 5(7), 1113-1116. DOI: 10.13189/ujer.2017.050704.

*Çayır, A. ve Balcı, E. (2017). Bireyselleştirilmiş okuma programının disleksi riski olan bir ilkokul öğrencisinin okuma becerileri üzerindeki etkisi. Uluslararası Türkçe Edebiyat Kültür Eğitim Dergisi, 6(1), 455-470. Erişim adresi: https://dergipark.org.tr/tr/download/article-file/284276

*Çeliktürk Sezgin, Z. ve Akyol, H. (2015). Okuma güçlüğü olan dördüncü sınıf öğrencisinin okuma becerilerinin geliştirilmesi. Turkish Journal of Education, 4(2), 4-16. DOI: 10.19128/turje.181115.

*Dağ, N. (2010). Okuma güçlüğünün giderilmesinde 3P metodu ile boşluk tamamlama (cloze) tekniğinin kullanımı üzerine bir çalışma. Ankara Üniversitesi Eğitim Bilimleri Fakültesi Özel Eğitim Dergisi, 11(1), 63-74. DOI: 10.1501/Ozlegt_0000000146.

*Dağlı Gökbulut, Ö., Akçamete, G. ve Güneyli, A. (2020). Birlikte öğretim uygulamalarının özel gereksinimli ilkokul öğrencilerinin okuduğunu anlama becerilerine etkisi. Elektronik Sosyal Bilimler Dergisi, 19(74), 879-894. DOI: 10.17755/esosder.592673.

Deniz, M. E., Yorgancı, Z. ve Özyeşil, Z. (2009). Öğrenme güçlüğü görülen çocukların sürekli kaygı ve depresyon düzeylerinin incelenmesi üzerine bir araştırma. Ilköğretim Online, 8(3), 694-708. Erişim adresi: https://dergipark.org.tr/tr/pub/ilkonline/issue/8597/106989

Deveci, M. ve Koç, E. S. (2020). Öğrenme güçlüğü konusunda yayınlanmış makalelerin karşılaştırmalı olarak incelenmesi, WoS ve TR Dizin örneği. Insan ve Toplum Bilimleri Araştırmaları Dergisi, 9(5), 4088-4120. Erişim adresi: http://www.itobiad.com/tr/pub/issue/57287/774509

*Dinç, R. (2017). Okuma Güçlüğü yaşayan öğrencide okuma becerisini geliştirmeye yönelik bir eylem araştırması. Kuramsal Eğitimbilim Dergisi, 10(2), 320-334. DOI: 10.5578/keg.27774.

Doğan, S. ve Delialioğlu, Ö. (2020). A systematic review on use of technology in learning disabilities. Ankara University Faculty of Educational Sciences Journal of Special Education, 21(3), 611-638. DOI: 10.21565/ozelegitimdergisi.563763.

*Doğuyurt, M. F. ve Doğuyurt, S. B. (2016). Okuma güçlüğü çeken öğrencilerin okuma becerisinin geliştirilmesine yönelik bir çalışma: Bir eylem araştırması. 21. Yüzyılda Eğitim ve Toplum, 5(14), 275-286. Erişim adresi: https://dergipark.org.tr/tr/pub/egitimvetoplum/issue/32111/355986

Drigas A. S. ve loannidou, R. E. (2013). ICT's in special education: A review. In M. D. Lytras, D. Ruan, R. D. Tennyson, P. Ordonez de Pablos, F. J. García Peñalvo, L. Rusu. (Eds.) Information Systems, Elearning, and Knowledge Management Research (pp. 357-364). DOI: 10.1007/978-3-64235879-1_43.

Duran, E. ve Öztürk, E. (2019). Türkçe öğretiminde ölçme ve değerlendirme. H. Akyol ve A. Şahin (Ed.), Türkçe öğretimi içinde (ss. 263-282). Ankara: Pegem Akademi.

*Duran, E. ve Sezgin, B. (2012a). Rehberli okuma yönteminin akıcı okumaya etkisi. Gazi Üniversitesi Gazi Eğitim Fakültesi Dergisi, 32(3), 633-655. Erişim adresi: http://www.gefad.gazi.edu.tr/tr/pub/issue/6734/90521

* Duran, E. ve Sezgin, B. (2012b). Yankılayıcı okuma yönteminin akıcı okumaya etkisi. Ondokuz Mayıs Üniversitesi Eğitim Fakültesi Dergisi 2012, 31(2), 145-164. Erişim adresi: https://dergipark.org.tr/tr/download/article-file/187981

* Dündar, H. ve Akyol, H. (2014). Okuma ve anlama problemlerinin tespiti ve giderilmesine ilişkin örnek olay çalışması. Eğitim ve Bilim, 39(171), 361-377. Erişim adresi: http://egitimvebilim.ted.org.tr/index.php/EB/article/view/1991

*Ege, B. (2019). Okuma güçlüğünün giderilmesinde akıcı okuma stratejilerinin etkisi (Yayımlanmamış yüksek lisans tezi). Bayburt Üniversitesi Lisansüstü Eğitim Enstitüsü, Bayburt.

*Ekiz, D., Erdoğan, T. ve Uzuner, F. G. (2011). Okuma güçlüğü olan bir öğrencinin okuma becerisinin geliştirilmesine yönelik bir aksiyon araştırması. Abant İzzet Baysal Üniversitesi Eğitim Fakültesi Dergisi, 11(2), 111-131. Erişim adresi: https://app.trdizin.gov.tr/publication/paper/detail/TVRNek56STVPUT09 
Türkiye'de Okuma Güçlüğünü Gidermeye Odaklanan İlkokul Düzeyindeki Araştırmaların İncelenmesi: 20002020 Dönemi

Ekşi Sınır, G. (2020). Özel öğrenme güçlüğü tanısı almış ve almamış öğrencilerin problem çözme, dikkat becerileri ve yönetici işlevlerinin karşılaştırılması (Yayımlanmamış yüksek lisans tezi). Marmara Üniversitesi Eğitim Bilimleri Enstitüsü, İstanbul.

Ekwall, E. E. ve Shanker, J. L. (1988). Diagnosis and remediation of the disabled reader. (Third edition). Allynand Bacon, Inc.

Engelmann, S., Meyer, L., Carnine, L., Becker, W., Eisele, J. ve Johnson, G. (1999). Corrective reading decoding level B: Decoding strategies. Columbus, $\mathrm{OH}$ : Science Research Associates.

Fielding-Barnsley, R. (2000). Reading disability: The genetics connection and appropriate action. Washington DC: ERIC Clearinghouse.

Gough, D., Thomas, J. ve Oliver, S. (2012). Clarifying differences between review designs and methods. Systematic Reviews, 1(28), 1-9. DOI: 10.1186/2046-4053-1-28.

*Görgün, B. (2018). Akıcı okuma ve okuduğunu anlama destek eğitim programının (OKA2DEP) özel öğrenme güçlügü olan öğrencilerin okuma becerilerine etkisi (Yayımlanmamış doktora tezi). Eskişehir Osmangazi Üniversitesi Eğitim Bilimleri Enstitüsü, Eskişehir.

Görgün, B. ve Melekoğlu, M. A. (2019). Türkiye'de özel öğrenme güçlüğü alanında yapılan çalışmaların incelenmesi. Sakarya University Journal of Education, 9(1), 83-106. DOI: 10.19126/süje.456198.

Grunêr, S., Ötsberg, P. ve Hedenius, M. (2018). The compensatory effect of text-to-speech technology on reading comprehension and reading rate in Swedish schoolchildren with reading disability: The moderating effect of inattention and hyperactivity symptoms differs by grade groups. Journal of Special Education Technology, 33(2), 98-110. DOI: 10.1177/0162643417742898.

*Gül, M. (2019). Okuma güçlüğü yaşayan ilkokul 4.sınıf öğrencisinin öğrenme stiline uygun zenginleştirilmiş öğretim yöntemleriyle okuma güçlüğünün giderilmesi (Yayımlanmamış yüksek lisans tezi). Zonguldak Bülent Ecevit Üniversitesi Sosyal Bilimler Enstitüsü, Zonguldak.

Güneş, F. (2020). Türkçe öğretimi yaklaşımlar ve modeller. Ankara: Pegem Akademi.

*Gürbüz, A. (2015). Altı dakika yönteminin akıcı okumaya etkisi (Yayımlanmamış yüksek lisans tezi). Uşak Üniversitesi Sosyal Bilimler Enstitüsü, Uşak.

Heckelman, R. G. (1969). A neurological-impress method of remedial-reading instruction. Academic Therapy, 4(4), 277-282. DOI: 10.1177/105345126900400406.

Hemingway, P. ve Brereton, N. (2009). What is a systematic review? Retrieved from: www.whatisseries.co.uk

Herrmann, J. A., Matyas, T. ve Pratt, C. (2006). Meta-analysis of the nonword reading deficit in specific reading disorder. Dyslexia, 12, 195-221. DOI: 10.1002/dys.324.

Higgins, J. P., Thomas, J., Chandler, J., Cumpston, M., Li, T., Page, M. J. ve Welch, V. A. (2019). Cochrane handbook for systematic reviews of interventions. New York: John Wiley \& Sons.

Hudson, R. F., Lane, H. B. ve Pullen, P. C. (2005). Reading fluency assessment and instruction: What, why, and how? The Reading Teacher, 58(8), 702-714. DOI: 10.1598/RT.58.8.1.

Hultquist, A. M. (2006). An introduction to dyslexia for parents and professionals. London: Jessica Kingsley Publishers.

Inhot, G., Matsoff, J., Gavin, J. ve Hendrickson, L. (2001). Read naturally. St. Paul. MN: Read Naturally.

illker, Ö. ve Melekoğlu, M. A. (2017). İlköğretim döneminde özel öğrenme güçlüğü olan öğrencilerin yazma becerilerine ilişkin çalışmaların incelenmesi. Ankara Üniversitesi Eğitim Bilimleri Fakültesi Özel Eğitim Dergisi, 18(3), 443-469. DOI: 10.21565/ozelegitimdergisi.318602.

*ilter, i. (2018). Zayıf okuyucuların okuduğunu anlama becerilerinin geliştirilmesinde ana fikir belirleme becerisinin öğretimi. Ankara Üniversitesi Eğitim Bilimleri Fakültesi Özel Eğitim Dergisi, 19(2), 303-334. DOI: 10.21565/ozelegitimdergisi.315887.

James, W. (2004). Special education and social development. New Delhi: Anmol Publications.

Joseph, L. M. (2002). Helping children link sound to print: Phonics procedures for small-group or wholeclass settings. Intervention in School and Clinic, 37(4), 217-221. DOI: 10:1177/105345120203700404. 
Karaçam, Z. (2013). Sistematik Derleme Metodolojisi: Sistematik derleme hazırlamak için bir rehber. Dokuz Eylül Üniversitesi Hemşirelik Yüksekokulu Elektronik Dergisi, 6(1), 26-33. Erişim adresi: https://dergipark.org.tr/tr/pub/deuhfed/issue/46815/587078

*Karasakaloğlu, N. ve Saraçı Çelik, S. (2018). Rehberle okuma yönteminin ilkokul öğrencilerinin dinlediğini anlama düzeyleriyle akıcı okuma becerilerine etkisi. Turkish Studies Educational Sciences, 13(19), 1083-1100. DOI: 10.7827/TurkishStudies.14096.

Karcıoğlu, R. (2020). Disleksi tanısı almış ve almamış çocuklarda çizgi roman ve hikâye kitaplarında okuduğunu anlamanın karşılaştırılması (Yayımlanmamış yüksek lisans tezi). Ankara Üniversitesi Sağlık Bilimleri Enstitüsü, Ankara.

*Kardaş İşler, N. ve Şahin, A. E. (2016). Bir ilkokul 4. sınıf öğrencisinin okuma bozukluğu ve anlama güçlüğü: Bir durum çalışması. Ana Dili Eğitimi Dergisi, 4(2), 174-186. DOI: 10.16916/aded.23121.

*Kaşdemir, B. (2020). Özel öğrenme güçlüğü olan bir öğrencinin okuduğunu anlama becerisinin tahmininceleme-özetleme örgütleme- değerlendirme (TiÖD) okuduğunu anlama stratejisi ile geliştirilmesi (Yayımlanmamış yüksek lisans tezi). Zonguldak Bülent Ecevit Üniversitesi Sosyal Bilimler Enstitüsü, Zonguldak.

Kato, S. (2012). Bridging theory and practice: Developing lower-level skills in L2 reading. The Language Learning Journal, 40(2), 193-206. Retrieved from: https://eric.ed.gov/?id=EJ968530

Kaya, D. ve Doğan, B. (2016). Birinci sınıf öğrencilerinin akıcı okumalarının değerlendirilmesi. Turkish Studies, 11(3), 1435-1456. DOI: 10.7827/TurkishStudies.9283.

Keskin, H. K. (2012). Akıcı okuma yöntemlerinin okuma becerileri üzerindeki etkisi (Yayımlanmamış doktora tezi). Gazi Üniversitesi Eğitim Bilimleri Enstitüsü, Ankara.

Kızılkaya, H. (2021). Disleksili öğrencilerle çalışan öğretmenler için geliştirilen eğitim programının ögrretmen yeterliklerine etkisinin incelenmesi (Yayımlanmamış doktora tezi). Necmettin Erbakan Üniversitesi Eğitim Bilimleri Enstitüsü, Konya.

King-Sears, M. E. ve Evmenova, A. S. (2007). Premises, Principles, and processes for integrating technology into instruction. Teaching Exceptional Children, 40(1), 6-14. DOI: 10.1177/004005990704000101.

*Kodan, H. (2015). Koro, tekrarlı ve yardımlı okuma yöntemlerinin zayıf okuyucuların okuma ve anlama becerileri üzerine etkisi (Yayımlanmamış doktora tezi). Gazi Üniversitesi Eğitim Bilimleri Enstitüsü, Ankara.

Koons, H. H. (2008). The reading-writing connection: An investigation of the relationship between reading ability and writing quality across multiple grades and three writing discourse modes (Unpublished doctoral dissertation). University of North Carolina, North Carolina.

*Kuruyer, H. G. (2014). Zenginleştirilmiş okuma programının okuma güçlügü olan öğrencilerin bilişsel süreç ve nöral yapılarına etkisi (Yayımlanmamış doktora tezi). Gazi Üniversitesi Eğitim Bilimleri Enstitüsü, Ankara.

Kuruyer, H. G. ve Özdemir, O. (2019). Okuma ve yazma güçlüklerinin tanılanması ve giderilmesi. H. Akyol ve A. Şahin (Ed.), Türkçe öğretimi içinde (s.243-260). Ankara: Pegem Akademi.

Küçükcaymaz, S. (2011). Okuma güçlüğü olan ilköğretim birinci ve ikinci kademe öğrencilerinin benlik saygı düzeylerinin karşılaştırılması (Yayımlanmamış yüksek lisans tezi). Marmara Üniversitesi Eğitim Bilimleri Enstitüsü, İstanbul.

Liederman, J., Kantrowitz, L. ve Flannery, K. (2005). Male vulnerability to reading disability is not likely to be a myth: A call for new data. Journal of Learning Disabilities, 38(2), 109-129. DOI: $10.1177 / 00222194050380020201$.

Lyon, G. R., Fletcher, J. M. ve Barnes, M. C. (2003). Learning disabilities. In E. J. Mash ve R. A. Barkley (Eds.), In Child psychopathology (p.520-586). New York: Guilford Press.

Mastropieri, M. A. ve Scruggs, T. E. (1997). Best practices in promoting reading comprehension in students with learning disabilities 1976 to 1996. Remedial and Special Education, 18(4), 198213.DOI: 10.1177/074193259701800402.

Mercer, C. D. (1997). Students with learning disabilities. New Jersey: Prentice Hall. 
Türkiye'de Okuma Güçlüğünü Gidermeye Odaklanan İlkokul Düzeyindeki Araştırmaların İncelenmesi: 20002020 Dönemi

Moher, D., Liberati, A., Tetzlaff, J., Altman, D. G. ve The PRISMA Group. (2009). Preferred reporting items for systematic reviews and meta-analyses: The PRISMA statement. PLoS Med, 6(7), 1-6. DOI: 10.1371/journal.pmed.100009.

Morrison, J. (2016). DSM-5'i kolaylaştıran 'klinisyenler için tanı rehberi'. (M. Şahin, Çev. Ed.). Ankara: Nobel.

Moule, P., Aveyard, H. ve Goodman, M. (2016). Nursing research: An introduction. New York: Sage.

Narimani, M. ve Aghajani, S. (2004). Learning disorders. Ardebil: Bagh-e Rezvan Publications.

National Reading Panel. (2000). Teaching children to read: An evidence-based assessment of the scientific research literature on reading and its implications for reading instruction. Washington, DC: National Institute of Child Health and Human Development.

O'Connor, D. M., Shapiro, H. L. ve Stoddard, K. (1998). Computer-based training of auditory temporal processing improves phonologic awareness of children with reading disability. Journal of Developmental \& Behavioral Pediatrics, 19(5), 382. Retrieved from: https://journals.Iww.com/jrnldbp/Citation/1998/10000/Computer_Based_Training_of_Audit ory_Temporal.19.aspx

* Okur, A. ve Öztürk, D. (2018). Okuma becerisinin geliştirilmesinde grafiksel sembollerin kullanımına yönelik örnek olay çalışması. Akra Kültür Sanat ve Edebiyat Dergisi, 6(14), 235-251. DOI: 10.31126/akrajournal.356872.

*Özbek, A. B. (2014). Öğrenme güçlüğü olan öğrencilerin okuma akıcılığını geliştirmede tablet bilgisayar destekli sağaltım programının etkililiği (Yayımlanmamış yüksek lisans tezi). Dokuz Eylül Üniversitesi Eğitim Bilimleri Enstitüsü, İzmir.

*Özdemir, O. (2013). ilköğretim öğrencilerinin öğrenme stillerine göre okuma güçlüklerinin giderilmesi (Yayımlanmamış doktora tezi). Gazi Üniversitesi Eğitim Bilimleri Enstitüsü, Ankara.

* Özkara, Y. (2010). Okuma güçlüğü olan öğrencilerin okuma düzeylerinin geliştirilmesine yönelik bir uygulama. Pamukkale Üniversitesi Sosyal Bilimler Enstitüsü Dergisi, 5, 109-119. Erişim adresi: https://dergipark.org.tr/tr/pub/pausbed/issue/34716/383810

Özmen, R. (2017). Öğrenme güçlüğü hakkında temel bilgiler ve uygulamalar. Ankara: Eğiten Kitap.

Paige, D. D. (2011). "That sounded good!": Using whole-class choral reading to improve fluency. The Reading Teacher, 64(6), 435-438. DOI: 10.1598/RT.64.6.5.

Parodi, G. (2007). Reading-writing connections: Discourse-oriented research. Reading and Writing, 20, 225-250. DOI: 10.1007/s11145-006-9029-7.

*Peksoy, M. (2018). Okuma güçlüğü çeken öğrencilerin okuma becerilerini geliştirmede tekrarlı okuma tekniğinin kullanımı üzerine bir durum çalışması (Yayımlanmamış yüksek lisans tezi). Gaziantep Üniversitesi Eğitim Bilimleri Enstitüsü, Gaziantep.

Pennington, B. F. (2002). The development of pyschopathology: Nature or nurture. New York: Guilford Press.

Pilten, G. (2017). İlk okuma yazma sürecinde ölçme ve değerlendirme. F. Susar Kırmızı ve E. Ünal (Ed.), ilk okuma yazma öğretimi içinde (ss. 383-419). Ankara: Anı.

Polloway, E. A., Serna L., Patton, J. R. ve Bailey, J. W. (2013). Strategies for teaching learners with special needs. New York: Pearson.

Pürsün, T. ve Sarı, H. (2019). Özel öğrenme güçlüğü olan öğrencilerin okuduğunu anlama becerilerine ilişkin çalışmaların incelenmesi. Turkish Special Education Journal: International, 3(2), 37-60. Erişim adresi: https://dergipark.org.tr/en/pub/tseji/issue/53862/655258

Rasinski, T. V. (2010). Why reading fluency should be hot!. The Reading Teacher, 65(8), 516-522. DOI: 10.1002/TRTR.01077.

Rasinski, T. V., Padak, N., Linek, W. ve Sturtevant, E. (1994). Effects of fluency development on urban second-grade readers. The Journal of Educational Research, 87(3), 158-165. Retrieved from: https://www.jstor.org/stable/27541913

Rayner, K., Foorman, B. R., Perfetti, C. A., Pesetsky, D. ve Seidenberg, M. S. (2001). How psychological science informs the teaching of reading. Psychological Science in the Public Interest, 2(2), 3174. https://doi.org/10.1111/1529-1006.00004 
Rello, L. ve Baeza-Yates, R. (2013). Good fonts for dyslexia. ASSETS 2013: Proceedings of the 15th International ACM SIGACCESS Conference on Computers and Accessibility, 1-8. DOI: $10.1145 / 2513383.2513447$.

Reutzel, D. R. ve Cooter, R. B. (2012). Teaching children to read: The teacher makes the difference. New York: Pearson.

Rutter, M., Caspi, A., Fergusson, D., Horwood, L. J., Goodman, R., Maughan, B., Moffitt, T. E., Meltzer, H. ve Carroll, J. (2004). Sex differences in developmental reading disability: New findings from 4 epidemiological studies. JAMA, 291(16), 2007-2012. DOI: 10.1001/jama.291.16.2007.

*Sağlam, Ö. (2019). Tekrarlı ve yankılayıcı okuma yöntemlerinin 3. sınıf öğrencilerinin okuma becerilerine etkisi (Yayımlanmamış yüksek lisans tezi). Gazi Üniversitesi Eğitim Bilimleri Enstitüsü, Ankara.

Saine, N. L., Lerkkanen, M. K., Ahonen, T., Tolvanen, A. ve Lyytinen, H. (2011). Computer-assisted remedial reading intervention for school beginners at risk for reading disability. Child Development, 82(3), 1013-1028. DOI: 10.1111/j.1467-8624.2011.01580.x.

Samuels, S. J. (2006). Reading fluency: Its past, present, and future. In T. V. Rasinski, C. L. Z. Blachowicz and K. Lems (Eds.), In Fluency instruction: Research-based best practices (p.7-20). New York: Guilford.

Santrock, W. J. (2018). Eğitim psikolojisi. (D. M. Siyez, Çev. Ed.). Ankara: Nobel.

Saviour, P., Kumar, S., Kiran, U., Ravuri, R. R., Rao, V. R. ve Ramachandra, N. B. (2008). Allelic variants of DYX1C1 are not associated with dyslexia in India. Indian Journal of Human Genetics, 14(3), 99-102. DOI: 10.4103/0971-6866.45002.

Seçkin Yılmaz, Ş. ve Baydık, B. (2017). Okuma performansı düşük olan ve olmayan ilkokul öğrencilerinin okuma akıcılıkları. Illkögrretim Online, 16(4), 1652-1671. DOI: 10.17051/ilkonline.2017.342983.

Seçkin, Ş. (2012). Okuma güçlüğü olan ve olmayan ilköğretim öğrencilerinin okuma akıcılıkları (Yayımlanmamış yüksek lisans tezi). Ankara Üniversitesi Eğitim Bilimleri Enstitüsü, Ankara.

*Sert, C. (2019). Okuma güçlüğü olan öğrencilerin okuma akıcılığının arttırılmasında model okuma, tekrarlı okuma, hata düzeltme ve kendini izleme stratejisi sağaltım paketinin etkisi (Yayımlanmamış yüksek lisans tezi). Gazi Üniversitesi Eğitim Bilimleri Enstitüsü, Ankara.

Seyis, G. (2021). Disleksili Çocuklarda yazı yazma performansı ve performans algısının karşılaştırılması (Yayımlanmamış yüksek lisans tezi). Hacettepe Üniversitesi Sağlık Bilimleri Enstitüsü, Ankara.

Shaywitz, B. A., Shaywitz, S. E., Pugh, K. R., Mencl, W. E., Fulbright, R. K., Skudlarski, P., Constable, R. T., Marchione, K. E., Fletcher, J. M., Lyon, G. R. ve Gore, J. C. (2002). Disruption of posterior brain systems for reading in children with developmental dyslexia. Biological Psychiatry, 52(2), 101-110. DOI: 10.1016/s0006-3223(02)01365-3.

*Sidekli, S. (2010a). Ilköğretim 5. sınıf öğrencilerinin okuma ve anlama becerilerini geliştirme (eylem araştırması) (Yayımlanmamış doktora tezi). Gazi Üniversitesi Eğitim Bilimleri Enstitüsü, Ankara.

*Sidekli, S. (2010b). Eylem araştırması: İlköğretim dördüncü sınıf öğrencilerinin okuma ve anlama güçlüklerinin giderilmesi. Türklük Bilimi Araştırmaları, 27, 563-580. Erişim adresi: https://dergipark.org.tr/tr/pub/tubar/issue/16968/177248

*Sidekli, S. ve Yangın, S. (2005). Okuma güçlügü olan öğrencilerin okuma becerilerinin geliştirilmesine yönelik bir uygulama. Kazım Karabekir Üniversitesi Eğitim Fakültesi Dergisi, 11, 393-413. Erişim adresi: https://dergipark.org.tr/tr/pub/ataunikkefd/issue/2772/37094

Siegel, L. S. (2006). Perspectives on dyslexia. Paediatrics \& Child Health, 11(9), 581-587. DOI: 10.1093/pch/11.9.581.

*Sirem, Ö. (2020). Okuma destek programının ilkokul öğrencilerinin okuma güçlüğü sağaltımına etkisi (Yayımlanmamış doktora tezi). Hacettepe Üniversitesi Eğitim Bilimleri Enstitüsü, Ankara.

Snow, C. E., Burns, M. S. ve Griffin, P. (1998). Preventing reading difficulties in young children. Washinhton DC: National Academy Press.

Snowling, M. J. ve Melby Lervag, M. (2020). Oral language deficits in familial dyslexia: A meta-analysis and review. Psychological Bulletin, 142(5), 498-545. DOI: 10.1037/bul0000037. 
Türkiye'de Okuma Güçlüğünü Gidermeye Odaklanan İlkokul Düzeyindeki Araştırmaların İncelenmesi: 2000 2020 Dönemi

*Sözen, N. (2017). Okuma güçlüğü olan öğrencilerin anlama becerilerinin geliştirilmesinde rehberli okuma yöntemi'nin etkisi (Yayımlanmamış doktora tezi). Gazi Üniversitesi Eğitim Bilimleri Enstitüsü, Ankara.

Spandel, V., Nathan, R. ve Robb, L. (2001). Daybook of critical reading and writing. Willmington, MA: Great Source Education Group.

Stahl, S. A. ve Heubach, K. M. (2005). Fluency-oriented reading instruction. Journal of Literacy Research, 37(1), 25-60. DOI: 10.1207/s15548430jIr3701_2.

Stanovich, K. (2000). Progress in understanding reading. New York: Guilford.

Sugara, Y. (2012). The effect of using shared reading strategy toward reading comprehension of the second year students at state senior high school 12 Pekanbaru (Unpublished bachelor dissertation). State Islamic University of Sultan Syarif Kasim Riau Faculty of Education and Teacher Training, Pekanbaru.

*Şahin, F. ve Çakır, R. (2018). Çoklu ortam materyallerinin okuma-yazma güçlüğü çeken öğrencilerin okuma-yazma becerileri üzerinde etkisi. Journal of Instructional Technologies \& Teacher Education, $\quad 7(2), \quad 75-90 . \quad$ Erişim adresi: https://dergipark.org.tr/tr/pub/jitte/issue/41978/467460

*Şahin, M. ve Baştuğ, M. (2020). Okuma güçlüğünü gidermede nörolojik etki yönteminin rolü. Academy Journal of Educational Sciences, 4(2), 93-101. DOI: 10.31805/acjes.814139.

Şahin, R. (2019). Sınıf öğretmenlerinin disleksiye yönelik bilgi ve tutumlarının incelenmesi (Yayımlanmamış yüksek lisans tezi). Tokat Gaziosmanpaşa Üniversitesi Eğitim Bilimleri Enstitüsü, Tokat.

Şen, N. (2016). Okuma güçlüğü çeken ortaokul öğrencilerinin okuma becerilerinin incelenmesi (Yayımlanmamış yüksek lisans tezi). Dokuz Eylül Üniversitesi Eğitim Bilimleri Enstitüsü, İzmir.

*Taşkaya, S. M. (2010). Okuma Problemlerinin Giderilmesinde Renkli Metinlerin Etkisi. Ondokuz Mayıs Üniversitesi Eğitim Fakültesi Dergisi, 29(2), 21-36. Erişim adresi: https://app.trdizin.gov.tr/makale/TVRFME1qQXINZz09/okuma-problemleriningiderilmesinde-renkli-metinlerin-etkisi

Topal, E. (2019). Disleksili çocuklarda Dinamik Yürüme Indeksi'nin Türkçe geçerlilik ve güvenirliliğinin araştırılması (Yayımlanmamış yüksek lisans tezi). Marmara Üniversitesi Sağlık Bilimleri Enstitüsü, İstanbul.

Tosun, D. (2019). ilkokul öğretmenlerinin disleksi bilgisi ve algısı üzerine ölçek geliştirme (Yayımlanmamış yüksek lisans tezi). Boğaziçi Üniversitesi Sosyal Bilimler Enstitüsü, İstanbul.

Tracey, D. H. ve Morrow, L. M. (2006). Lenses on reading. New York: The Guilford.

*Türkmenoğlu, M. (2016). Illkokulda akran öğretimi aracılığıyla okuma güçügünün giderilmesi (Yayımlanmamış yüksek lisans tezi). Niğde Üniversitesi Eğitim Bilimleri Enstitüsü, Niğde.

Uğur, F. (2018). Ortaokul 7. sınıf öğrencilerinin okuduğunu anlama ve yazma başarıları arasındaki ilişki. Okuma Yazma Eğitimi Araştırmaları, 6(1), 1-12. Erişim adresi: https://dergipark.org.tr/tr/pub/oyea/issue/38104/417849

*Ulu, H. ve Akyol, H. (2016). The effects of repetitive reading and PQRS strategy in the development of reading skill. Eurasian Journal of Educational Research, 63, 225-242. DOI: 10.14689/ejer.2016.63.13.

*Ulu, H. ve Başaran, M. (2013). Video öz değerlendirme tekniğinin akıcı okuma becerisinin gelişimine etkisi. Dumlupınar Üniversitesi Sosyal Bilimler Dergisi, 38, 1-10. Erişim adresi: https://dergipark.org.tr/tr/pub/dpusbe/issue/4780/65879

*Urfalığlu Eroğlu, G. (2020). Improving reading abilities in dyslexia with neurofeedback and multisensory learning (Unpublished doctoral dissertation). Sabancı University Graduate School of Engineering and Natural Sciences, İstanbul.

*Uzunkol, E. (2013). Akıcı okuma sürecinde karşılaşılan sorunların tespiti ve giderilmesine yönelik bir durum çalışması. Mersin Üniversitesi Eğitim Fakültesi Dergisi, 9(1), 70-83. Erişim adresi: https://dergipark.org.tr/tr/pub/mersinefd/issue/17382/181537

Vachon V., Gleason, M. M. ve Archer, A. L. (2001). The REWARDS ${ }^{\circledR}$ program. Seattle, WA: VoyagorSopris Learning. 
Vellutino, F. R., Fletcher, J. M., Snowling, M. J. ve Scanlon, D. M. (2004). Specific reading disability (dyslexia): what have we learned in the past four decades?. Journal of Child Psychology and Psychiatry, and Allied Disciplines, 45(1), 2-40. DOI: 10.1046/j.0021-9630.2003.00305.x.

Vilger, M. P. (2008). Reading fluency: A bridge from decoding to comprehension research brief. Ottawa: Outoskills.

Walker, M. M. ve Rastatter, M. P. (2003). The influence of vocabulary age and spatial dimension on rapid picture naming in children with reading disorders. Journal of Communication Disorders, 36(4), 307-319. Retrieved from: https://eric.ed.gov/?id=EJ673023

Ward, L. B. (2001). Dyslexia and the university: Canadian dyslexia centre report. Retrieved from: https://www.dyslexiachampions.org/media/adults-with-dyslexiaresources/universityanddyslexia.pdf

Westwood, P. (2001). Reading and learning difficulties approaches to teaching and assessment. Australia: ACER Press.

Woolfolk-Hoy, A. (2015). Eğitim psikolojisi. (D. Özen, Çev.). İstanbul: Kaknüs.

*Yamaç, A. (2015). İlkokul dördüncü sınıf düzeyinde bir öğrencinin sesli okuma akıcılığını artırmaya yönelik bir uygulama. Kastamonu Eğitim Dergisi, 23(2), 631-644. Erişim adresi: https://dergipark.org.tr/tr/pub/kefdergi/issue/22599/241427

*Yangın, S. ve Sidekli, S. (2006). Okuma güçlüğü yaşayan öğrencilerin kelime tanıma becerilerinin geliştirilmesine yönelik bir uygulama. Muğla Üniversitesi Sosyal Bilimler Enstitüsü Dergisi, 16. Erişim adresi: https://dergipark.org.tr/tr/pub/musbed/issue/23524/250641

Yıldız, M. ve Çetinkaya, E. (2017). The relationship between good readers' attention, reading fluency and reading comprehension. Universal Journal of Educational Research, 5(3), 366-371. DOI: 10.13189/ujer.2017.050309.

Yıldız, M. ve Melekoğlu, M. A. (2020). Özel öğrenme güçlüğü olan bireylerin okuduğunu anlama becerileri konusunda gerçekleştirilmiş araştırmaların incelenmesi. Inönü Üniversitesi Eğitim Fakültesi Dergisi, 21(3), 1274-1303. DOI: 10.17679/inuefd.770066.

*Yılmaz, M. (2006). ilköğretim 3. sınıf öğrencilerinin sesli okuma hatalarını düzeltmede ve okuduğunu anlama becerilerini geliştirmede tekrarlı okuma yönteminin etkisi (Yayımlanmamış yüksek lisans tezi). Gazi Üniversitesi Eğitim Bilimleri Enstitüsü, Ankara.

Yurdakal, i. H. (2014). Ilkokullarda okuma güçlüğünde yaşanan sorunlar ile eğitim uygulamalarına ilişkin öğretmen ve öğrenci görüşleri (Yayımlanmamış yüksek lisans tezi). Pamukkale Üniversitesi Eğitim Bilimleri Enstitüsü, Denizli.

Yurdakal, İ. H. (2017). Disleksi (okuma güçlüğü). F. Susar Kırmızı ve E. Ünal (Ed.), ilı okuma yazma öğretimi içinde (ss. 421-461). Ankara: Anı.

*Yücel, D. (2009). Sesbilgisel farkındalık (fonolojik farkındalık) eğitiminin okuma sorunu olan çocuklar üzerindeki etkisinin incelenmesi (Yayımlanmamış yüksek lisans tezi). Hacettepe Üniversitesi Sağlık Bilimleri Enstitüsü, Ankara.

*Yüksel, A. (2010). Okuma güçlüğü çeken bir öğrencinin okuma becerisinin geliştirilmesine yönelik bir çalışma. Kuramsal Eğitimbilim, 3(1), 124-134. Erişim adresi: https://keg.aku.edu.tr/arsiv/c3s1/c3s1m8.pdf

Ziegler, C. J., Perry, C., Ma-Wyatt, A., Ladner, D. ve Schulte-Körne, G. (2003). Develop mental dyslexia in different languages: Language-specific or universal? Journal of Experimental Child Psychology, 86(3), 169-193. DOI: 10.1016/S0022-0965(03)00139-5.

Not: Derlemeye dahil edilen çalışmalar $(*)$ işareti ile gösterilmiştir.

\section{Extended Abstract}

\section{Introduction}

Reading is an essential skill for individuals' academic and social life. However, some students are not successful in reading processes (Tracey \& Morrow, 2006) and suffer from reading disability. The reading disability can be defined as having problems with correct reading, reading speed, fluent reading, and reading comprehension despite having average intelligence and education opportunities (American Psychiatric Association, 2013). It is also stated that the reading difficulty can be seen in $3 \%$ 
Türkiye'de Okuma Güçlüğünü Gidermeye Odaklanan İlkokul Düzeyindeki Araştırmaların İncelenmesi: 20002020 Dönemi

and $20 \%$ of people (Rello \& Baeza Yates, 2013). It can be said that fluent reading strategies such as guided reading (Yurdakal, 2017), repeated reading (Bender \& Larkin, 2003), and choral reading (Paige, 2011) are primarily used to overcome reading disabilities. In addition, practices as Fernald Technique (Polloway et al., 2013), Reward Reading Program (Vachon, Gleason \& Archer, 2000), and Multi-Sensory Reading Methods (Mercer, 1997) can also be used to overcome reading disabilities.

In the literature, various research is conducted about reading disabilities. However, studies examining intervention practices to overcome reading difficulties are lacking. Thus, within the scope of studies between 2000-2020 in Turkey, the following essential question is sought to answer in this study:

- What are the general characteristics, features of both participants and intervention practices of primary school-level research focusing on reading disabilities?

\section{Method}

In this study, the systematic review method is used. The systematic review process was carried out in the suggested stages by Moher et al. (2009). Specific compatibility criteria have been determined to examine related studies. This criterion is to be carried out with primary school students, including intervention practices, published between 2000-2020 and published in refereed journals. Online databases are searched with keywords by the research criteria

As a result of the database search, 8922 studies were found. The studies which are searched in different databases (1426), studies in other fields (4037), studies without intervention practices (904), studies not conducted at primary schools (1277), and studies not performed with Turkish students (863) are excluded because of not complying with specific compatibility. The full texts of the remaining 415 studies were examined in detail, and 357 studies were also excluded. The remaining 58 studies were analyzed by using a template. In the analysis of the data, descriptive analysis for some dimensions (year of publication, method, sample, gender, etc.) and inductive content analysis approach for some dimensions (personal characteristics, results of intervention practices, etc.) were used.

\section{Result and Discussion}

According to the results of the research, it is seen that the studies were carried out more intensively in the last decade. It is similar to other review studies (Görgün \& Melekoğlu, 2019; Pürsün \& Sarı, 2019). Legal arrangements for special education, the proliferation of special education schools, developments in diagnosis processes, and especially the spread of postgraduate special education programs were deemed more important in the last two decades. The most used research designs in these research are action research, case study, and single-subject research. According to results of Deveci and Koç (2020) and Yıldız and Melekoğlu (2020), it showed that experimental research designs are frequently used in studies involving intervention practices. The most used data collection tool in research is the "Informal Reading Inventory", because it is more practical than other data collection tools in measuring fluent reading and reading comprehension (Akyol et al., 2014). It was concluded that the research were primarily conducted with fourth-grade students. Studies in the literature show that reading disabilities studies are mostly carried out with the senior classes of primary school or secondary school (Görgün \& Melekoğlu, 2019; Pürsün \& Sarı, 2019).

Specific standard features of students suffering from reading disability are academic underachievement, indifference to lessons, low-level education of their families, lack of attention, and focusing problems. It is seen that these features overlap with the features that Yurdakal (2017) describes the basic symptoms that can be observed in individuals with reading difficulties. It is concluded that many studies used fluent reading strategies, methods and techniques, various strategies (3P, PQRS, neurological impacts, etc.), and individualized reading programs. Considering the individuals have difficulties in fluent reading, it was the most preferred intervention practices are fluent reading strategies. Research results showed that the intervention practices increase reading speed, word recognition, prosodic reading, reading comprehension, reading motivation, phonological awareness, oral reading, attention, memory performance, and reading skills, and reduce reading 
errors. However, the reading speed, the word recognition averages are less than students with typical development, while reading mistakes are more.

Based on results, in addition to reading disabilities, research on writing, speaking, and listening skills of students are recommended. The results indicate that designing, practicing, and testing technology-supported intervention programs to overcome reading difficulties is needed. Standardized measurement tools that can be used in the evaluation of standard program designs and reading skills for intervention practices can be developed. Finally, it can be said that students who have reading disabilities are needed to develop social and emotional skills. 